\title{
OVERCOMING THE POST-STRUCTURALIST METHODOLOCIAL DEFICIT - METAPRAGMATIC MARKERS AND INTERPRETIVE LOGICS IN A CRITIQUE OF THE BOLOGNA PROCESS
}

\author{
Jan Zienkowski
}

\begin{abstract}
This paper argues for an integration of post-structuralist and linguistic pragmatic perspectives on discourse as a response to the post-structuralist methodological deficit. In order to make his argument, the author presents and illustrates the logics approach to discourse, subjectivity and hegemony as presented by Jason Glynos and David Howarth. This post-structuralist approach constitutes a response to the methodological deficit that haunts much of post-structuralist discourse theory. Nevertheless, it does not provide a linguistic toolbox for analysis. Zienkowski argues that the logics approach can be brought to bear on empirical analysis through the notion of metapragmatic markers. These are linguistic tools that allow us to investigate the self-interpretations of individuals. The practical relevance of using metapragmatic markers in the identification of interpretive logics will be illustrated by means of an analysis of a critical response to the implementation of the Bologna process in Germany. Zienkowski studies Dietrich Lemke's critical article called Mourning Bologna published in a special issue of E-flux journal $\mathrm{n}^{\circ} 14$ devoted to the Bologna process. More specifically, he investigates how Lemke constructs his critical stance. Throughout this process, Zienkowski proposes an interpretive and functionalist heuristic for identifying the interpretive logics operative in his text by means of a functional analysis of metapragmatic markers. He concludes with an argument for integrating both perspectives while emphasising that any articulation of post-structuralist and linguistic pragmatic theories of discourse involves some significant reconsiderations with respect to the indexical and differential theories of meaning that characterise each perspective respectively.
\end{abstract}

Keywords: Post-structuralism; Linguistic pragmatics; Articulation; Interpretive logic; Contextualised self-interpretations; Metalinguistics; Metapragmatics; Metapragmatic awareness; Indexicality; Deixis; Bologna; Critical discourse.

\section{Introduction: Linguistic pragmatics as a form of post-structuralist thought}

It is both inaccurate and incorrect to oppose linguistic pragmatics and post-structuralist discourse analysis as incompatible perspectives. In spite of manifold differences in terminology, style, and theories, authors associated with these approaches to discourse tend to share a number of postulates with respect to the ways in which subjectivity and meaning are generated in and through discursive practice(s). 
Post-structuralist discourse theory is usually associated with the writings of theorists as varied as Jacques Derrida, Michel Foucault, Gilles Deleuze, Jacques Lacan, Slavoj Žižek, Judith Butler, Ernesto Laclau, and Chantal Mouffe. Insights of these authors have been taken up throughout the humanities in fields as diverse as history, linguistics, anthropology, geography, sociology, theology, and political theory. Interestingly, the same may be said about many pragmaticians. Pragmatics is often associated with the work of ordinary language philosophers such as Ludwig Wittgenstein, J.S. Austin, H. Paul Grice, and John Searle. Pragmatics may also refer to work carried out within the context of sociolinguistics, the ethnography of speaking, linguistic anthropology, conversation analysis, psycholinguistics, enunciative linguistics or translation studies. Debates on the delineation of the field of pragmatics are hardly settled. Its boundaries can be tightened to the study of a limited number of phenomena such as speech acts and conversational implicatures. They may also be broadened to include the writings of pragmatist philosophers such as William James, George H. Mead, Jürgen Habermas or Richard Rorty.

Post-structuralist theorists of hegemony might say that both pragmatics and poststructuralism are over-coded and over-determined empty signifiers. Pragmaticians, in turn, may emphasise that these concepts perform a variety of functions and indicate a multiplicity of perspectives in studies of discourse and subjectivity. Their meaning, therefore, is negotiated in whatever context they are deployed by speakers and hearers, whenever they are interpreted by hearers or readers. Nevertheless, both groups of authors would concur in their rejection of a context-free understanding of the labels marking their identities. Both perspectives stress the reflexivity, heterogeneity, and historical contingency of meaning production.

The most general principle informing both approaches is probably the idea that there are no one-to-one relationships between semiotic forms and their functions. A second principle states that the generation of meaning requires both explicit and implicit aspects of communication. We convey these meanings by articulating differential semiotic elements with one another, and by indexically pointing to relevant aspects of context. There is a stronger claim to be made as well: Linguistic pragmatics simply is a form of post-structuralist thought, just as post-structuralism can be framed as a variant of pragmatics. For this reason, we need explicit markers that guide our interpretation processes, but the functions and meanings of these markers can never be exhausted or fixed in an ultimate way. A third principle shared by both perspectives pertains to the notion of context. In neither perspective context functions independently of discourse. This is not to say that there is no world external to discourse. It simply means that we have no way to give meaning to this world without the discursive means that allow us to articulate and imagine relationships with each other and with the world.

Gumperz articulated one of the main pragmatic arguments against most forms of structuralism: We cannot investigate interpretations on the basis of decontextualized claims about the nature of a language (langue). He pointed out that when structuralists such as Boas, Sapir, or Whorf speak of language structure, "they generally refer to abstract features derived by decontextualizing procedures which take into account only a portion of the totality of signs that may enter into the interpretation of communicative acts" (Gumperz 1982: 16). In a similar vein, Emile Benveniste, the pioneer of French enunciative pragmatics, put it as follows: "nothing is in language that has not been before in discourse" (Benveniste 1974 quoted in: Johansson and Suomela-Salmi 2011: 81). Language should not be considered in terms of a reified structure. It should be 
considered in terms of a series of intersubjective and reflexive processes, actions, and strategies deployed by speakers and hearers. Interlocutors are always involved in a negotiation wherein the assessment of one another's communications is at stake (Gumperz 1982: 153). Moreover, humans are at least partly aware of what they are doing in discourse (Verschueren 2000: 444). As such, linguistic pragmatics constituted a reaction against the structuralist presuppositions present in the work of linguists such as Noam Chomsky, who aimed at an a-contextual account of the grammatical rules and structures organizing linguistic activity. The linguistic pragmatic response to the structuralist tradition implied a focus on the various functions of communicative acts. It also implied a focus on reflexive actors - no matter whether these are described in terms of speakers, writers, interlocutors, communicators, individuals, voices, or subjects.

Just like pragmaticians, post-structuralists reject a concept of language conceptualised as a closed and centred system of differences. They agree that an analysis of linguistic or discursive difference is key to understanding inter-subjective processes and they reject the idea that these differences can be located in a closed system whose limits can be identified in an objective way. However, the prime target of traditional post-structuralist critique is not so much the unified concept of language, but the idea of a unified and centred subject as the source and sine-qua-non of meaning, interpretation, and knowledge. Usually, representatives of the post-structuralist tradition stop short of using linguistic tools to analyze linguistic material. While poststructuralists have taken up linguistic models in order to reinvigorate social and political theory, pragmaticians are usually less prone to abstract epistemological debates on the limits of the 'autonomous subject'.

Linguistic pragmaticians are more likely to account for the ways in which oral and written texts function with respect to the construction of subjects in and through discourse. They devote considerable attention to the complex indexical functions performed in the production of discourse. Meaning and interpretation are considered to be generated through a process in which subjects are oriented by formal markers and cues that point to relevant spatial, temporal, social, and/or (inter)textual co-ordinates of reality. Thus, as the meaning of pronouns shifts according to their usage in a particular context of enunciation, pronouns function indexically in the sense that the interpretation of what a pronoun means depends on one's ability to functionally relate such a signifier to relevant aspects of context by engaging in a variety of inferential processes. Pragmaticians thus tend to advocate a concept of discourse and meaning going beyond differential and grammatical models.

Another key difference between most post-structuralist and linguistic pragmatic approaches has to do with the metaphorical nature of discourse. Both types of authors rely on metaphors in order to construct their particular perspectives on discourse, subjectivity, or whatever other concept they wish to investigate. For instance: Within pragmatics we find a great deal of dramaturgical metaphors among authors who make use of the work of Erving Goffman; pragmaticians working from the perspective of enunciative linguistics may try to identify a polyphony of voices; or they may deploy technological metaphors as Sperber and Wilson do when they talk about human beings as "efficient information-processing devices" (Sperber and Wilson 1986 quoted in Robinson 2006: 10).

But whatever metaphors linguistic pragmaticians may deploy, they use them in order to highlight specific features of language use. Post-structuralists however, take linguistic categories and tend to use them as metaphors in order to conceptualise the processual and intersubjective aspects of socio-political objects. These processes are not 
necessarily (merely) of a linguistic nature. Thus, Judith Butler uses Austin's notion of performativity in order to produce claims about the various ways in which identities and subjectivities are performatively embodied; in the Archaeology, Foucault mobilizes enunciative metaphors to elucidate the specific modalities in which socio-historical knowledge claims exist; Laclau and Mouffe draw upon Saussurean ideas in their claim that it is just as impossible to impose societal boundaries as it is impossible to fix the boundaries and meanings of any type of discourse or meaning; the same goes for the logics approach of Howarth and Glynos which is also based upon Saussure's differential theory of discourse. Many post-structuralist authors, therefore, have found theoretical inspiration in linguistic models in their attempt to de- and/or re-construct supposedly fixed meanings, identities, and subjectivities. However, this does not entail that they actually deploy linguistic methodologies or that they are interested in the empirically observable features of symbolic interaction. This has resulted in a problem that has been labelled as the methodological deficit of post-structuralist discourse theory - a problem I aim to address in this article.

It is not my intention to discuss all possible combinations of post-structuralist and linguistic pragmatic thought. Rather, by means of a restricted focus on one particular form of discourse theory in which the methodological deficit has been acknowledged explicitly (the logics approach to discourse formulated by David Howarth and Jason Glynos), and by means of a restricted focus on a particular set of pragmatic phenomena (markers of metapragmatic awareness), I hope to demonstrate how this deficit may be overcome. I will argue that an articulation of post-structuralist and linguistic pragmatic perspectives allows us to empirically analyse complex patterns in interpretive and socio-political processes. The Essex approach to discourse as developed by Laclau, Mouffe, Torfing, Howarth, and Glynos will be introduced to illustrate this point.

Whereas the Essex approach to discourse is often deployed in the analysis of large-scale socio-political processes, linguistic pragmatics seems to offer a perspective and a toolbox that is best suited to analyse relatively small-scale interactions and linguistic phenomena. Nevertheless, a reduction of linguistic pragmatic principles to mere methodology does not do justice to the variety of its complex theoretical postulates. In fact, I maintain that an integration of linguistic pragmatic focus into poststructuralist discourse theories may help post-structuralists to overcome their methodological deficit. Especially the pragmatic notions of context, indexicality and metapragmatic awareness provide us with useful tools to achieve this goal. Individuals are more or less aware of what they are doing when producing in discourse. Quite often, they leave traces or markers of this awareness in discourse. Such metapragmatic markers allow us to investigate the specific ways in which individuals establish coherence between potentially contradictory statements, discourses and practices. They allow for an empirical investigation of the way in which people engage in large-scale self-interpretations and for an analysis of the ways in which they articulate themselves with complex socio-political phenomena in and through language use.

The practical relevance of using metapragmatic markers in the identification of large-scale interpretive logics will be illustrated by analysing a critical response to the implementation of the Bologna process in Germany. This paper contains a case-study of Dietrich Lemke's critical article called Mourning Bologna, published in a special issue of E-flux journal $\mathrm{n}^{\circ} 14$ devoted to the Bologna process. I will ask how Lemke is able to construct his critical stance and present a heuristic for linking the pragmatic study of 
metapragmatic markers to the post-structuralist concept of discursive logics. For these purposes, I will outline key concepts required to understand the post-structuralist logics approach of Howarth and Glynos. I will argue that this approach can be brought to bear on an empirical analysis of Lemke's text by linking the notion of logic to the concept of markers of metapragmatic awareness. Mourning Bologna will then be investigated by means of an interpretive and functionalist heuristic compatible with the frameworks outlined in this article. However, before I set out to do so, it remains for me thank my friends and colleagues for their useful comments and insights ${ }^{1}$.

\section{On metapragmatic markers of interpretive logics}

Below, I will explain the theoretical concepts used in the analysis. I will introduce the notion of articulation as posited by Ernesto Laclau and Chantal Mouffe. This concept lies at the basis of the logics approach to discourse and subjectivity as further developed by Jason Glynos and David Howarth. The latter two's logics approach will be introduced as a response to the methodological deficit that characterises much poststructuralist discourse theory. It should be emphasised that this approach seeks to analyse social and political processes and discourses taking the self-interpretations of subjects into account. This move opens up a theoretical space that allows us to go beyond a Saussurian linguistics of difference alone, and towards a pragmatic linguistics that takes the principle of indexicality into account. On the other hand, the notion of articulation will be discussed as a research practice. Against this theoretical background, I will introduce the notion of metapragmatic markers as a means to empirically investigate the contextualised self-interpretations of individuals as generated through the production of discourse.

\subsection{Laclau and Mouffe on articulation}

One of the most important notions in the logics approach to discourse is the concept of articulation as developed by Laclau and Mouffe in Hegemony and socialist strategy (Laclau and Mouffe 1985). In this book, Laclau and Mouffe put forward their discourse theory centred on the concept of articulation. Even though Laclau would come to reframe his discourse theory by integrating Lacanian (see: Glynos and Stavrakakis 2004; Stavrakakis 1999) and Butlerian (see: Butler et al. 2000; Butler 2000; Laclau 2000a, 2000b; Žižek 2000) insights, I will restrict myself to a discussion of articulation as he originally posited it in collaboration with Chantal Mouffe. In spite of the fact that the notion of articulation has been deployed in structuralist semiotics as well (see: Chandler 2002: 6-7), Laclau and Mouffe make no explicit reference to this fact. It is

${ }^{1}$ I would like to thank: Roel Coesemans for his feedback on speech act verbs and modality, Matylda Weidner for her notes on quotation marks as discourse markers, Sarah Scheepers for her insights on frames and self-referential expressions, as well as Petra Heyse and Stefanie Peeters for their critical comments to the analysis. I would also like to thank my supervisor Jef Verschueren for his remarks on metapragmatic comments and for sussing out some ambiguities in the analysis. Lastly, I am indebted to Johannes Angermüller for our many discussions on post-structuralist and linguistic thought as well as for his useful comments on this article in general. Also, some of the statements made within the introduction of this article have been formulated in a co-authored draft of an introduction to a collective but unpublished volume on linguistic pragmatics and post-structuralism. 
also interesting to note that their own concept of articulation as a discursive and social connection between meaningful elements was adopted by Stuart Hall in his cultural studies approach to discourse and society. The latter accepted the double sense of articulation as theorised by Laclau and Mouffe but rejected their analytical decision to analyse all social phenomena in terms of discourse (Daryl Slack 1996; Grossberg 1986a, 1986b).

Laclau and Mouffe posit the notion of articulation as the key principle informing the production of all discourse, meaning, subjectivity and politics. They consider discourse to be the result of a practice of articulating semiotic elements to one another. Discourse is the structured totality emerging from a multiplicity of articulations (Laclau and Mouffe 1985: 105). In Hegemony and socialist strategy, they provide us with two explicit definitions of articulation. Their first definition of articulation goes as follows:

"we will call articulation any practice establishing a relation among elements such that their identity is modified as a result of the articulatory practice" (Laclau and Mouffe 1985: 105)

The authors never explicitly discuss what these articulated elements might be. However, they use the notion of articulation in reference to elements that belong to various levels of discursive organisation: Identities, subject positions, statements, narratives, genres, and theories. Their first definition highlights the sense of articulation as a type of connection established through social practice. When we produce discourse, we relate various practices, concepts, narratives, and other discursive elements to one another. The above definition also points out that the meaning of the articulated elements is altered through the very practice of articulation. In order to understand this, we have to take a closer look at the language philosophical elements of the discourse theory of Laclau and Mouffe.

Laclau and Mouffe claim that meaning is not produced as an effect of the closed structure of language where all elements are designated a differential position, but as an effect of the relative fixation of discursive elements to one another. Whereas Saussure considered the value or the meaning of a sign to be a result of the arbitrary relationship between a signifier and a signified, Benveniste pointed out that "to say that the values are 'relative' means that they are relative to each other" (Benveniste 1971 quoted in: Laclau and Mouffe 1985: 106). Laclau and Mouffe refer to Benveniste when they consider every articulated discursive element to be constitutive for the meaning or value of the element it is articulated with (Laclau and Mouffe 1985: 106-07; Torfing 1999: 95). It is interesting to note that they do not refer to Benveniste's enunciative linguistics (see: Johansson and Suomela-Salmi 2011; Roulet 1996; Van Hecke 2002) but to an isolated structuralist argument. As such, they don't have to take the principle of indexicality into account. On the other hand, Laclau and Mouffe do not refer to a reified syntagmatic or paradigmatic structure that pre-exists the subject. They adopt the idea that the relationship between signifier and signified is arbitrary, but amend this Saussurean idea by claiming that the meaning or value of a sign is generated by means of its articulation with other signs in actual discourse. They favour a notion of articulation as a practice of connecting relatively unfixed discursive elements (see Laclau and Mouffe 1985: 112; Stavrakakis 1999; Torfing 1999: 98).

At this point, an important caveat needs to be acknowledged. The impossibility of an ultimate fixation of meaning does not preclude a partial fixation of meaning. According to Laclau and Mouffe, absolute non-fixation of meaning is an impossibility 
as well. If there were no possibility of partially fixing the relationship between a signifier and its signified(s), the very possibility of difference and dispersion of meaning would be pre-empted. The main question, then, is how this partial fixation of meaning is achieved. Here, we arrive at the second definition of articulation given by Laclau and Mouffe.

"The practice of articulation therefore, consists in the construction of nodal points which partially fix meaning; and the partial character of this fixation proceeds from the openness of the social, a result, in its turn, of the constant overflowing of every discourse by the infinitude of the field of discursivity" (Laclau and Mouffe 1985: 112)

In this sense, articulation refers to a node in a chain of discourse that connects various discursive elements to one another. It forms a conceptual point of juncture between various social actors. The infinitude of the field of discursivity which overflows every articulation and every nodal point refers to the infinity of potential articulations and meanings. For now, it suffices to say one or two things about the notion of nodal point ${ }^{2}$ as articulated in this second definition.

Laclau and Mouffe consider discourses as attempts "to dominate the field of discursivity, to arrest the flow of differences, to construct a centre" from which we can start to give meaning to ourselves, our practices, and our world. Within concrete discourses, some signifiers are given a central place that partially fixes the meaning of the signifying chain. These signifiers are called nodal points. However, it is important to keep in mind that - like another signifier - every nodal point is given within an intertextuality that overflows it (Laclau and Mouffe 1985: 110-13). A nodal point is a kind of knot of meanings that unifies a discursive field constituted by a multitude of discursive elements (Žižek 1995: 95). In order to clarify the political implications of this point, Laclau would later develop the concept of the empty signifier ${ }^{3}$ (see Laclau 1994a: 44-45; Torfing 1999: 301). Illustrations of how such concepts have been deployed in post-structuralist discourse theory may be found in a variety of readers (Howarth et al. 2000; Howarth and Torfing 2005; Laclau 1994b).

The impossibility of ultimately fixing meaning outside of a specific context of discursive articulation basically amounts to the idea that a semiotic form can perform any number of functions depending on the particular discursive chains in which it is articulated. Put differently, there is no one to one relationship between a (linguistic) semiotic form and its context either. In his correspondence with Judith Butler, Laclau is quite explicit on the notion of context. He points out how on the one hand, "... it is not possible to, strictly speaking, attribute closed boundaries to a context". We find ourselves in the paradoxical situation in which it is impossible to fully delimit contexts. Put differently: "contexts have to be defined by their limits, and yet these limits are impossible" to fix. The solution lies - as always within the framework of Laclau and Mouffe - in a relative fixation of meaning. It is through an imaginary assumption of existing limits, that we are able "to fix (to close within itself) a transient context" (Butler and Laclau 2004: 335) that provides the conditions for meaning, politics, subjectivity, and hegemony.

\footnotetext{
${ }^{2}$ The notion of nodal point is an adaptation and translation of the Lacanian point de capiton.

${ }^{3}$ A signifier that is so over-coded with meanings that it means everything and nothing at the same time (see Laclau 1994: 44-45; Torfing 1999: 301). Empty signifiers are the topical objects of hegemonic struggle in public debate and in political praxis.
} 
Laclau implicitly maintains that context is always generated throughout articulatory practices. However, in conformity with the overall methodological deficit characterising most of the Essex writings on discourse and subjectivity, we will find no discussion of how contextual limits and partial fixations of meaning are realised in empirically observable discourse. In fact, the lack of a more fine-grained account of how context is (re)produced through empirically observable discourse is probably one of the main obstacles to overcoming the post-structuralist methodological deficit.

\subsection{A logics approach to discourse and subjectivity}

The logics approach to discourse advocated by Howarth and Glynos is a response to the post-structuralist methodological deficit. As we will see, their concept of articulation as a research practice in which it is important to take the self-interpretations of individuals into account allows us to link post-structuralist discourse theory with linguistic pragmatic principles and with the concept of markers of metapragmatic awareness in particular. In the sections below, I will exemplify these post-structuralist and pragmatic concepts with reference to the Bologna process where possible.

\subsubsection{A response to the post-structuralist methodological deficit}

Howarth and Glynos accept the notion of articulation as developed by Laclau and Mouffe, but emphasise its heuristic implications. They also elaborate on the double concept of a logic of equivalence and a logic of difference as introduced by their mentors. According to Laclau and Mouffe, the formal logics of equivalence and difference structure discourse, politics, and subjectivity. We will introduce these notions as we go.

The book Logics of critical explanation (Glynos and Howarth 2007) is a response to a methodological deficit in post-structuralist discourse theory. Articles and case-studies that explicitly discuss and illustrate the way post-structuralist concepts such as empty signifier, logic or nodal point can be identified and analysed in empirically observable discourse are scarce. Authors hardly ever illustrate how they relate poststructuralist concepts to empirical objects of investigation and seldom indicate how research result results were generated (see: Howarth 2005; Torfing 2005). There are no sections on methodology in any of the articles collected in edited volumes such as Discourse theory and political analysis (Howarth et al. 2000) and The making of political identities (Laclau 1994b). Methodological discussions in Discourse theory and European politics are also quite limited (Howarth and Torfing 2005).

Most Essex authors disqualify the distinction between theory and method. However, all too often this leads to subsumptive practices. Many case studies basically amount to a projection of Essex concepts upon social processes and data. This is not to say that the empirical dimension is wholly ignored. The articles often deal with concrete political situations such as Argentine politics after Peronist populism (Barros and Castagnola 2000), resistance of new environmental movements against Manchester Airport's second runway (Griggs and Howarth 2000), identity and hegemony in former Yugoslavia (Saleel 1994) or the Palestinian issue (Bowman 1994). Moreover, the introductions to and the theoretical chapters of these readers display an increasing 
awareness of the problematics related to methodology. Nevertheless, in spite of this increasing interest, most articles remain silent with respect to the way terminology is being applied. There is no methodology in the sense of an explicit discussion of the heuristic guidelines that allow a researcher to articulate texts, concepts, and practices with one another in innovative ways.

Torfing acknowledges that the founders of discourse theory are "with a few exceptions, not very interested in these issues" (Torfing 2005: 25) . Nevertheless, he emphasises that these methodological challenges are important. At this point, most Essex-inspired studies illustrate pre-established theoretical arguments and do not attempt to learn from the empirical analysis. As Torfing puts it, because of the antipositivist stance of discourse theory, "discourse theorists have thrown the methodological baby out with the epistemological bath water" (Torfing 2005: 27). None of the defensive responses to the methodological challenges justify the systematic lack of critical reflection with regard to method and methodology within post-structuralist discourse theory: "there is an urgent need for critical, explicit and context-bound discussion of what we do in discourse analysis, why we do it, and what the consequences are" (Torfing 2005: 28). In addition to a linguistic turn in the social sciences, Angermüller argues that we need analytical models from linguistics in order to solve the question how to get from linguistic material that is empirically available to a more general knowledge about the discourse in which it originated (Angermüller 2008).

Early attempts to operationalise the rich framework provided by Laclau and Mouffe have started to appear. Their framework has been linked to approaches as varied as critical discourse analysis (see Fairclough and Chouliaraki 1999: 121-26), conversation analysis (see Wetherell 1998), and French enunciative linguistics (see: Johansson and Suomela-Salmi 2008; Maeße 2010). Unfortunately, the deployment of the Essex framework in these more methodologically sophisticated approaches to discourse has not led to a critical debate with(in) the post-structuralist discourse theories set out by Foucault, Laclau, Mouffe, Žižek, and Butler. Torfing argues that there is a great deal of unrealised potential within discourse theory that can only be developed if discourse theorists respond to three challenges: (1) the need to demonstrate the analytical value of discourse theory in empirical studies that take us beyond the mere illustration of arguments and concepts; (2) the need to address the core topics within social and political science and not be content with specializing in allegedly 'soft' topics such as gender, ethnicity, and social movements; (3) the need to critically reflect upon questions of method and research strategy without surrendering to the positivist obsession with method that is founded on the belief that the observation of a set of methodological rules somehow guarantees the truth of the research results (Torfing 2005: 25-28).

\subsubsection{Articulation as a research practice}

The idea of articulation as a method was already touched upon by Howarth in his book Discourse (Howarth 2000), but the most elaborate response to the methodological deficit to date has been formulated by Jason Glynos and David Howarth in Logics of critical explanation in social and political theory (Glynos and Howarth 2007). It reframes the principle of articulation as a method for doing discourse theory and discourse analysis. However, it still lacks a detailed account of how to deal with the linguistic and textual data that provide the raw material for any investigation into 
discourse. I wholeheartedly agree with the post-structuralist argument that there can be no pre-established method or set of rules that can be applied to all cases irrespective of the various contextual correlates of the research project. Nevertheless, a detailed account of how linguistic analysis can be articulated with post-structuralist discourse theory does not contradict this principle. On the contrary, I argue that such an articulation allows for a more critical deployment of theoretical concepts in empirical analyses. More specifically, I will focus on the usefulness of metapragmatic markers for an analysis of interpretive logics and the associated subjective self-interpretations of individuals.

Howarth argues that the notion of articulation can be invoked to understand the practices under investigation as well as the practices of social scientists themselves (Glynos and Howarth 2007: 180). This entails that every single step in the research process involves a practice of (re)articulation. Every stage - from the initial problematisation, over data production and collection (e.g. through focus groups, interviews, literature research, participant observation, data mining, ...) and analysis (transcription, the application of theoretical frameworks to the problematised object of investigation,...), to the presentation of research results (a book, a paper, a hand-out, a $\mathrm{PhD}, \ldots)$ - involves linking theories, practices, and self-interpretations to one another, while at the same time modifying their meanings (Howarth 2000: 140-41). Put differently, the production of scientific discourse is a highly disciplined practice of (re)articulation.

\subsubsection{Articulation and logics of critical explanation}

According to Laclau and Mouffe, two logics account for identity formation, political strategy and hegemonic struggle: A logic of equivalence and a logic of difference codefine the political imaginaries of social actors. The logic of equivalence simplifies political space (Laclau and Mouffe 1985: 130). It works through the establishment of a chain of equivalence that articulates various discursive elements with one another in opposition to another discursive element. Jens Maeße illustrates this logic with respect to the Bologna process as interpreted in Germany. He points out that various policy frames ${ }^{4}$ allow for an individualised deployment of particular vocabularies to explain this process: A university governance frame; an internationalisation frame; a study reform frame; a study grant frame; a top university frame; a gender frame; a university expansion frame; a quality frame; a Bologna frame; and a Europe frame (Maeße 2010: 135-44). I will not go into all of these frames here, but I will elaborate on the quality

\footnotetext{
${ }^{4}$ Maeße describes policy-frames as agendas for political reform that articulate specific goals, means and problematisations with one another (Maeße 2010: 135). With reference to Minsky, Maeße considers frames to be process oriented. They provide us with discursive elements and rules that allow us to deal with the particularities of a situation. Maeße uses the notion of frames in his analysis of the German hegemonic field with respect to the Bologna process. The following quote shows the close affinity between Maeße's interpretation of frames and the notion of logics as posited by Laclau, Mouffe, Howarth and Glynos: "Minskys Frame-Begriff eignet sich demnach als eine Methode zur Analyse des hegemonialen Feldes, weil damit die Elemente der Kontexte, auf die Texte zugreifen, katalogisiert werden können. Weder der Sinn noch die determinierende Kraft der Elemente des Kontextes stehen im Fokus der Analyse, sonder das schlichte Vorhandensein der Elemente und ihrer möglichen Beziehungen untereinander" (Maeße 2010: 125-126).
} 
frame in order to give more substance to the notion of logics as articulated by Laclau, Mouffe, Howarth, and Glynos.

Actors deploying the vocabulary of the quality frame tend to interpret the Bologna process as a process directed at a more rigorous evaluation of the products and services in the domains of science and education offered by the university. Universities should be held socially, economically, and scientifically accountable in terms of their efficient deployment of resources. Various practices should guarantee this accountability. Quality should be guaranteed by various practices lumped together in a system that regulates the Akkreditierung (accreditation), the Evaluation (evaluation), and the Rechnungslegung (accountability) of universities. Concrete practices that regulate teaching would include: An explicit formulation of required competences with respect to knowledge, understanding and abilities; specific end-goals that should be reached with respect to the allocation of Bachelor and Master degrees; a modular structuration of study programmes, and so on (Maeße 2010: 141-43).

Jens Maeße demonstrates that the most common nouns articulated by social actors who need to interpret what is meant by the concept of the Bologna process are basically interchangeable. This goes both for particular wordings as for the interpretive frames generated by these wordings. Here, we can observe the operation of a logic of equivalence: "From the point of view of hegemonic analysis, this means that the equivalent connection of the nouns "internationalisation", "quality", "competitiveness", "educational reform", and "Bachelor/Master" mobilise almost all of the policy frames identified above and none of the other frames would necessarily be disqualified" (Maeße 2010: 155) ${ }^{5}$. One of the results of a thoroughly expanded logic of equivalence is that it becomes increasingly difficult to think outside of the box provided by dominant and interchangeable discursive frames and concepts.

In addition to this chain of equivalence, there is also a logic of difference that accounts for practices of articulation. This logic works through the expansion of the system of difference by decomposing existing chains of equivalence and by a rearticulation of these elements in a new differential order. It expands and complicates political space (Laclau and Mouffe 1985: 130). Nevertheless, it should be pointed out that neither logic can dominate. Also, both logics are deployed throughout articulatory practices. Howarth points out that these political logics of equivalence and difference play a quasi-transcendental role in discourse theory, since they are integral to the construction and contestation of social relations and practices (Howarth 2005: 328).

Glynos and Howarth expand the concept of logic as used by their mentors. It should be noted that we are not talking about logics in the formal sense of the word. As Bourdieu noted: "Practice has a logic which is not that of logic" (Bourdieu cited in Flyvbjerg 2001: 38). In a similar vein, Glynos and Howarth conceptualise logic neither in terms of a formal analysis of propositions so as to determine their validity or truth, nor in terms of a predictive law such as in Marx's general law of capital accumulation. Rather, they state that " $a$ logic refers, first to the rules governing a practice, institution or system of relations between objects and, secondly, to the kinds of entities (and their relations) presupposed by the operation of such rules" (Howarth 2005: 323). The

${ }^{5}$ The original text reads as follows: ["Hegemonieanalytisch gesehen bedeutet dies, dass eine äquivalente Verknüpfung der Nomen "Internationalisierung”, "Qualität”, "Wettbewerbsfähigkeit", "Studienreform" und "Bachelor/Master" fast alle oben aufgeführten policy frames mobilisieren und keinen der anderen Frames notwendigerweise zurückweisen würde"] (Maeße 2010: 155). 
important thing about these rules is that they are contingent and interpretive. They do not function mechanically. The application and operation of rules in social conduct always requires some degree of interpretation, self-awareness, and value-rationality (Flyvbjerg 2001: 42-43, 47; Glynos and Howarth 2007: 49-82). For this reason, "interpretation cannot somehow be by-passed in the establishment of facts and correlations, because the interpretations of both researcher and researched are essential in determining what is to count as fact" (Glynos and Howarth 2007: 55). The main question to be answered at this point is how such logics can be identified.

The types of logics that may be identified are classified into three categories by Glynos and Howarth. They distinguish between political, social, and fantasmatic logics. We already discussed the political logics. These are simply the logics of equivalence and difference as described by Laclau and Mouffe. The social logics of critical explanation find themselves at a different level of abstraction. They are constructed by the researcher in order to explain particular conjunctures and events (Howarth 2005: 127). Whereas the political logics of equivalence and difference are extremely abstract, the social logics are more concrete. One might say that the latter give content to the operation of the political logics. It is possible to re-interpret the various frames identified by Jens Maeße as social logics. In this sense, the various signifiers used to signify the practices, concepts, and social actors associated with the concept of quality could be said to constitute (or to be constituted by) a social logic of qualification. In my own analysis of Lemke's Mourning Bologna, I will point out that Lemke constructs a neoliberal social logic that articulates a variety of practices, social actors, and other discursive elements in a chain of equivalence. On the other hand, Lemke implicitly constructs an alternative interpretive logic throughout his article: A critical social logic that characterises his preferred mode of subjectivity. He uses a multiplicity of metapragmatic forms and functions in order to distinguish between both types of interpretive logics.

A last set of logics described by Howarth and Glynos is of a fantasmatic nature. If the political logics of equivalence and difference capture how social practices come into being or are transformed, fantasmatic logics explain why specific practices grip subjects. At this point, the Essex authors take recourse to Lacanian theory (Glynos and Stavrakakis 2004; Stavrakakis 1999). The main function of fantasy is "not to set up an illusion that provides a subject with a false picture of the world, but to ensure that the radical contingency of social reality - and the political dimension of a practice more specifically - remains in the background" (Glynos and Howarth 2007: 145). With regard to social practices, fantasmatic logics reinforce the natural character of discursive elements and prevent their politisation. With respect to the political dimension of practices, fantasy can provide support for many of our political projects and choices. For instance, it is through fantasy that we may strive to achieve equality, democracy, or justice - ideals that can never be fully realised. According to Howarth and Glynos, fantasy promises "a fullness-to-come once a named or implied obstacle is overcome". Moreover, the operation of such a paradoxical fantasmatic logic provides an account for the many contradictions that characterise specific political discourses and practices (Glynos and Howarth 2007: 147-48). 


\subsubsection{Contextualised self-interpretations and investigations into subjectivity}

Glynos and Howarth emphasise that it is important to keep in mind the hermeneutic lesson that we take the self-interpretations of subjects into account when we name and identify these logics of critical explanation. These self-interpretations have to be contextualised with reference to the languages and vocabularies by which subjects articulate themselves (Glynos and Howarth 2007: 55-61). This is important, since an adequate study of political life involves "the interpretation of the beliefs and desires of those we study" (Bevir and Rhodes 2003 cited in Glynos and Howarth 2007: 61). The authors of Logics of critical explanation in social and political theory claim that "logics offer us a way to move between the world of self-interpretations and practices on the one hand, and our social science explanations and critiques on the other, in a way that avoids some of the problems associated with the hermeneutical and naturalist approaches" to social science. For this reason, a passage through self-interpretations is considered to be an important starting point for any empirical analysis of political practices even though it does not constitute the point of arrival (Glynos and Howarth 2007: 157).

Howarth and Glynos draw three methodological conclusions. First of all, any explanation must start with intentions and self-interpretations as articulated by subjects - not merely as part of the process of problematisation, but also in the identifications of the social, political, and fantasmatic logics themselves. Put differently, the identification/articulation of explanative logics implies a (re)articulation of empirically observable discursive material. Secondly, they emphasise that social logics are "contextdependent constructions that are retroductively posited as a function of the rules and structures that inform practices and regimes". In contrast, political and fantasmatic logics are more formal, but they do not predetermine the explanations and critical engagements. They provide the means for critical explanation without determining the outcomes. Processes of social science should therefore be understood in terms of articulation instead of subsumption (Glynos and Howarth 2007: 159-61). As such, critical explanation is part of the scientific articulatory practice in the sense of Laclau and Mouffe described as "any practice establishing a relation among elements such that their identity is modified as a result of the articulatory practice" (Laclau and Mouffe 1985: 105 cited in Glynos and Howarth 2007: 162). However, in spite of the warnings against subsumption, the question of how individuals relate themselves to relevant aspects of reality remains. Below, I will argue that an analysis in terms of Saussurean difference alone is insufficient. If the logics approach to discourse and subjectivity as articulated within the Essex approach is to develop an adequate account of interpretively established context, it will have to take the principle of indexicality into account.

The Essex approach to discourse is as much a theory of articulation as a theory of subjectivity. Initially, Laclau and Mouffe reduced the notion of subjectivity to subject positions. These positions had to be located in a Foucaultian discursive structure. Moreover, Laclau and Mouffe posited that the analysis of subject positions "cannot dispense with the forms of overdetermination of some positions by others - of the contingent character of all necessity which, as we have seen, is inherent in any discursive difference" (Laclau and Mouffe 1985: 116). All meaning, including the meaning of subject positions, is overdetermined by a multiplicity of differences. Later on, Laclau would come to revise his position somewhat. In an introduction to Žižek's The sublime object of ideology, he acknowledges that "... the category of 'subject' 


\section{Jan Zienkowski}

cannot be reduced to the 'positions of the subject', since before subjectivation the subject is the subject of a lack" (Laclau 1989: xii). This so-called lack is a Lacanian psycho-analytical concept (see also: Glynos and Stavrakakis 2004; Stavrakakis 1999). It refers to the idea that we lack a direct connection to an objective reality, because of the fact that our experience of reality is always mediated through language. Individuals will try to adopt identities, but will always find out that these identifications are always incomplete. Put differently, no signifier will fix the meaning of a self-interpretation once and for all. This renewed concept of subjectivity entails that the practice of articulating subject positions to one another is a vain but productive attempt to fix the identities of self and other. Subjectivity can therefore never be reduced to an identification of a particular subject position produced through discourse.

Within the logics approach of Howarth and Glynos, the notion of selfinterpretation enters the picture. In line with the insights of Lacan, Laclau and Mouffe, they state that "because each discursive construct is never fully constituted but essentially incomplete or lacking, the subject is also lacking and incomplete" (Glynos and Howarth 2007: 127). Glynos and Howarth do not conceptualise subjectivity as a passive effect of structures, nor as a matter of active self-determination (Glynos and Howarth 2007: 128). If we have to identify logics by passing through the selfinterpretations of subjects, this means that we have to analyse the ways in which an individual articulates itself with respect to relevant aspects of contextual reality as described below. Such a (re)articulation does not imply an intention to ultimately fix any of the meanings involved. On the other hand, this does not mean that anything goes. As we will see, metapragmatic markers are useful linguistic tools that may help us to distinguish between the (self-)interpreations and the related subjectivities under investigation. Even though a subjectivity may never be fixed in an ultimate way, metapragmatic markers allow us to investigate subjectivity in terms of an individual's attempt to establish coherence between explicitly or implicitly articulated subject positions, statements, discourses, and practices. However, a notion of subjectivity that takes a metapragmatic perspective into account can never be based on Saussurian principle difference alone.

\section{3. (Meta)pragmatic markers of interpretive logics}

Since we consider metapragmatic markers to be a particular set of pragmatic markers, we have to address what we understand by pragmatics and the associated principle of indexicality. A detailed description of these notions allows us to address the notion of metapragmatic markers directly. Metapragmatic markers will prove to be a very useful category to analyse the logics constitutive of self-interpretations marked in linguistic discourse. The notion of indexicality is key in this respect.

\subsubsection{Pragmatics, post-structuralism and the principle of indexicality}

In spite of the fact that the logics approach to discourse, subjectivity and society constitutes an elaborate theoretical framework for analysis, it does not provide a heuristic for dealing with empirical data. Below, I will introduce the notion of metapragmatic markers as a useful linguistic tool for the empirical analysis of 
interpretive logics that constitute subjectivities. However, the general line of argumentation should be considered as a demonstration of the way linguistic pragmatic insights might help researchers to overcome the post-structuralist methodological deficit. In contrast to approaches that restrict the field of linguistic pragmatics to the study of a restricted number of research topics such as speech acts, presupposition, implicature, or aspects of the conversational structure (see: Huang 2007; Levinson 1983), I prefer to take a broader view of pragmatics. As such, linguistic pragmatics may be defined as "the study of linguistic phenomena from the point of view of their usage properties and processes" (Verschueren 1999: 1). This preference is informed by the fact that it allows us to investigate more linguistic phenomena with a (meta)pragmatic dimension than the restricted list mentioned above.

The pragmatic perspective forces researchers to focus on the way processes of meaning generation are marked in discourse. More specifically, researchers investigate how language users establish relevant (aspects of) context through various intersubjective strategies and practices (Zienkowski 2011a). Linguistic pragmaticians hold that contexts are generated through the principle of indexicality. Indexicality may be defined as a semiotic process of generating meaning by means of contextualisation cues that point to spatial, temporal, social, and/or (inter)textual coordinates of reality. Indexicals may be linguistic or non-linguistic. In either case, they trigger a contextualisation process as defined below. Metapragmatic processes may be largely implicit. For instance, through marked transitions in register or dialect, a speaker may index a shift in relevant aspects of his or her identity within the context of a conversation. A speaker may address a party that has just entered a conversational setting by merely pointing his gaze towards the newcomer. In fact, every aspect of language use is partly indexical. It provides pointers towards the various aspects of reality we need to take into account in order to understand the communications at hand. On the other hand, we will notice that a speaker / writer may also mark his or her metapragmatic awareness explicitly by means of hedges or metapragmatic descriptions.

Context may be defined as the flexible and temporal result of a (meta)pragmatic process which triggers interpretive efforts whereby spatial, temporal, social, and/or (inter)textual co-ordinates of reality are indexed by interactants. These processes contribute to interactional clarity and/or to an imagined common ground (see also: Bauman and Briggs 1990: 68; Blommaert 2005: 251; Verschueren 1999: 77). Put in Essex terms: context can only be partially and temporarily be fixed. Most of the times, Essex authors say this about meaning. However, when Laclau theorises the notion of context explicitly, we noticed how similar arguments come to the fore (Butler and Laclau 2004: 335). On the other hand, we should note that the Essex approach to discourse does not contain a theory of indexicality. The Saussurian inheritance of this framework has led to a notion of meaning which is explained in differential terms alone. There is a logic of equivalence and a logic of difference operative at all levels of discursive articulation, but there is no theorization of a logic of indexicality. Since most Essex authors do not distinguish between linguistic and non-linguistic elements of discourse, the notion of indexicality seems to be superfluous. However, I argue that if one wishes to counter the methodological deficit by focusing on the linguistic aspects of discourse, the principle of indexicality and the associated linguistic pragmatic perspective should be taken into account. A similar point has been raised by Johannes Angermüller, who suggested that "while the more [structural] semiotic logic of poststructuralist discourse theory allows us to look into the articulation of hegemonized systems of differences, pragmatic discourse analysis focuses on the ambivalent and 
instable constitution of hegemonic meaning in specific discursive utterances" (Angermüller 2005: 11).

Angermüller explains how a failure to deal with the heterogeneous dimension of discourse has led many linguistic discourse analysts to abandon Saussure and to turn to some sort of pragmatics (Angermüller 2008). In French linguistic pragmatics this can be exemplified with reference to the work of Emile Benveniste. Laclau and Mouffe briefly quote this student of Saussure in order to highlight the differential nature of meaning: "Benveniste, for example, states with reference to Saussure's principle of value: 'to say that the values are "relative" means that they are relative to each other. Now, is that not precisely the proof of their necessity". Nevertheless, they tend to gloss over an important feature of Benveniste's thought. Angermüller points out that Benveniste considers utterances to function thanks to a whole series of particles that deictically point towards the contexts of utterance. Pronouns, adverbs, and adjectives such as 'me', 'here', and 'now' rendering person, place, and time visible, are particularly important in this respect. They function deictically. Angermüller argues that "according to Benveniste, these particles and their derivates constitute a system - the "formal apparatus of the utterance" through which subjectivity is inscribed into language. Texts are subjective insofar they operate with the formal traces of the utterances (marqueurs) and thus resort to the context of utterance" (Angermüller 2007: 8) ${ }^{6}$.

Even though Angermüller tends to focus on the French tradition in linguistic pragmatics (especially polyphonic theories of enunciation), he emphasizes that in Anglo-Saxon pragmatics too, there has been an increasing insistence on the idea that texts do not have an inherent meaning emanating from a single unified subject who merely expresses him- or herself in a text. He points out that in addition to French polyphonic theory, there is the Lacanian theory of the split subject which claims that we cannot speak without letting the Other speak with us as well. There is also Erving Goffman who argued that rather than being one single source, the actor must be divided in at least three different instances: The author, the principal, and the animator (Angermüller 2008). Nevertheless, the multiplicity of voices and meanings that may potentially be inferred from texts is limited by the operation of various interpretive rules that are triggered when we are confronted with various types of discursive markers. These markers function indexically. They show their objects by pointing to them "in the enunciation rather than by rendering a given signification" (Angermüller 2011: 2997). As we will see, metapragmatic markers are especially important when we wish to determine how interpretive logics, self-interpretations, and / or subjectivities are constituted in and through actual language use.

\subsubsection{On metapragmatic markers}

It should be pointed out that the phenomena discussed under the header of metapragmatics also figure in research on metalinguistics (Bublitz and Hubler 2007; Caffi 1998; Jaworski et al. 2004b, 2004a; Verschueren 2004). There is no consensus with respect to the delineation of these terms. In this paper, I prefer to take a pragmatic

6 "diese Partikel und ihre Derivate bilden nach Benveniste ein System - den "formalen Apparat der Äußerung”, über den die Subjectivität in die Sprache eingelassen ist. Texte sind demnach "subjctiv"als sie mit den formalen Abdrücken der Äußerung (marqueurs) operieren und den Äußerungskontext zugreifen" (Angermüller 2007: 8) 
stance with respect to the usage of these concepts. Blommaert points out that "every discourse simultaneously says something in itself (e.g. it describes a particular state of affairs 'out there') and about itself, about how that discourse should be interpreted, situated in relation to context, social relations, and so on. Such indexical levels can also be called 'metalinguistic' (i.e. about linguistic structure) or 'metapragmatic (i.e. about forms of usage of language)" (Blommaert 2005: 253). This description highlights just one of three senses of metapragmatics.

In addition to metapragmatics as defined above, the notion may refer to the theoretical debate on pragmatics defined as a scientific discipline or perspective irrespective of the specific definition given to this discipline. Moreover, metapragmatics may refer to the conditions that make speaker's language use possible and effective. In this article I am concerned with metapragmatics in a third sense, i.e. "the investigation of that area of the speaker's competence which reflects the judgments of appropriateness on one's own and other people's communicative behaviour". Caffi points out that "This metapragmatics deals with the 'know-how' regarding the control and planning of, as well as feedback on, the ongoing interaction" (Caffi 1998: 581). This sense is closely related to a particular view on language use described as "the adaptable and negotiable making of linguistic choices, both in production and in interpretation, from variable (and constantly varying) range of options in an interactive effort at generating meaning" (Verschueren 2004: 57).

The study of the metapragmatic aspects of language use involves a study of metapragmatic awareness. In this sense, metapragmatics is "concerned with linguistic traces of a speaker's awareness of the processes he or she is involved in" (Verschueren 2009: 22). Even though we do not have any direct access to the awareness of others and in spite of the fact that awareness is not measurable, reflexive or metapragmatic awareness leaves traces in language use (Verschueren 2004: 59). Verschueren points out that: "... language users know more or less what they are doing when using language. Self-monitoring, at whatever level of salience, is always going on. It is this aspect of language use in relation to the medium of adaptability [Vygotski's 'mind in society'] that I call reflexive or metapragmatic awareness. [ ...] Studying this type of awareness is crucial to an understanding of verbal behaviour because, like any other form of socialisation, language use is always interpreted, in the sense that the actors involved attach meaning to it, so that the actors' interpretations become part and parcel of what needs to be described and explained" (Verschueren 2004: 444-45). Reflexive awareness can be marked in discourse by means of a range of linguistic forms that can be placed under the heading of metapragmatic markers.

Almost all researchers in the field of pragmatics agree that metapragmatic markers are functional entities. This means that a variety of linguistic forms may perform a metapragmatic function. Even though there is a metapragmatic dimension to all language use, potential indicators of metapragmatic awareness include "all of Jakobson's 'shifters', Gumperz's 'contextualization cues' (such as instances of code switching), anything ever discussed under the labels 'discourse markers / particles' or 'pragmatic markers / particles' (such as anyway, actually, undoubtedly, I guess, you know, etc.), 'sentence adverbs' (such as frankly, regrettably), hedges (such as sort of, in a sense), instances of 'mention' vs 'use' (again as already suggested in Jakobson), as well as direct quotations, reported speech, and more implicitly embedded 'voices' " (Verschueren 2004: 446). I will not illustrate the deployment of all of these markers in 
the analysis below. I merely aim to provide the reader with a heuristic to analyse subjectivity in terms of logics and metapragmatic markers.

Metapragmatic awareness may be marked explicitly by means of metapragmatic markers or may be left largely implicit in discourse (Hübler and Bublitz 2007). An important caveat to be made is that it is impossible to achieve either full explicitness or full implicitness by means of language use (Verschueren 1999: 26-36). Several authors developed typologies of metapragmatic or meta-linguistic markers and their multiplicity of functions: Ken Hyland did so from a pragmatic and text-linguistic perspective (Hyland 2005); Wolfram and Bublitz took an explicit pragmatic stance (Bublitz and Hubler 2007); and Eun-Jo Noh framed the various forms and functions of metalinguistic markers within the framework of relevance theory (Noh 2000). In this paper, I am not so much concerned with particular typologies as I am with the ways in which the concept of metapragmatic language use may help us to understand the interpretive logics constitutive of political subjectivities and discourse. Nevertheless, it is useful to take a look at Verschueren's overview of explicit and implicit metalinguistic, metadiscursive or metapragmatic markers (Verschueren 2004: 61):

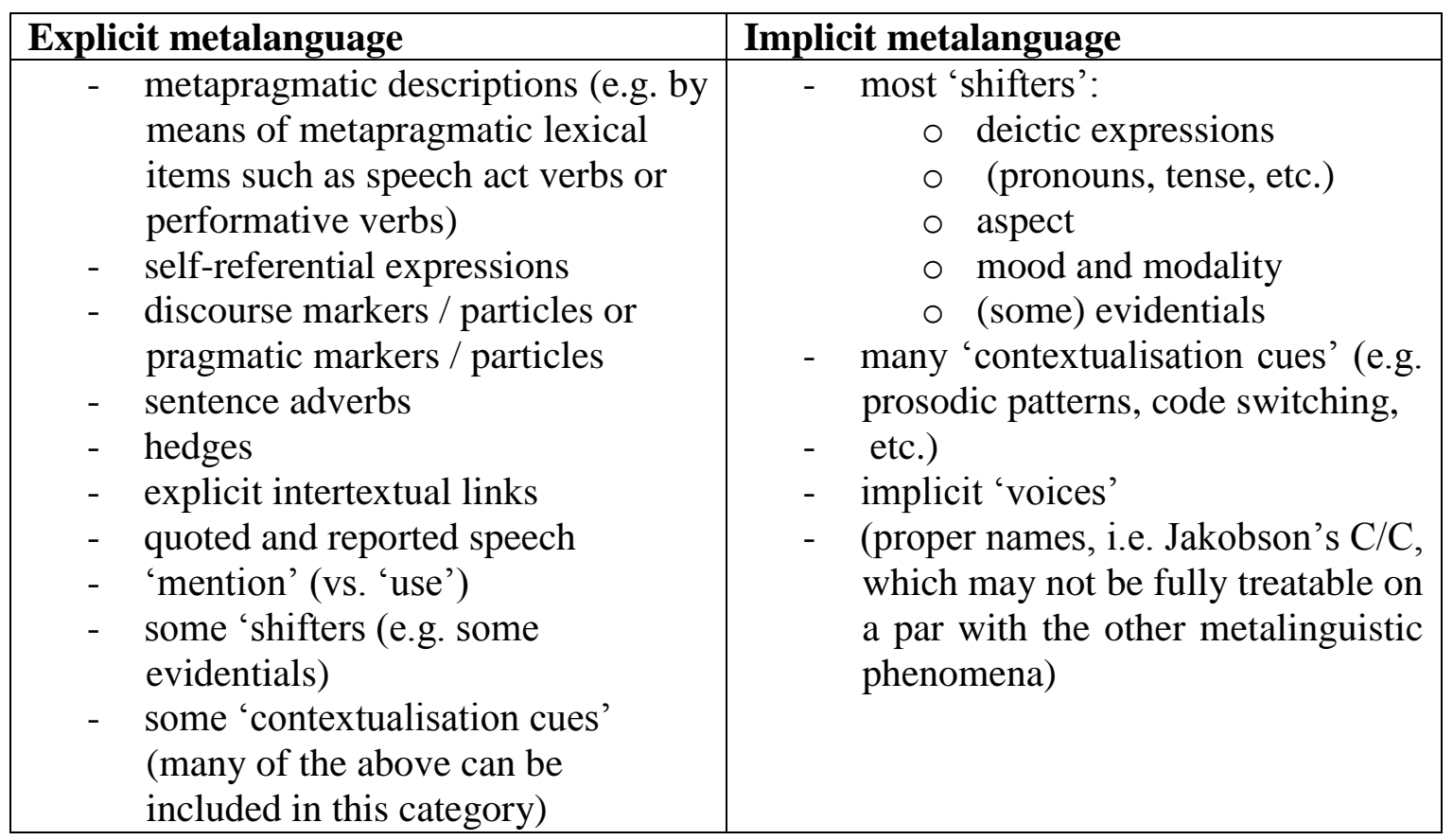

Table 1 - Table by Jef Verschueren (2004) - indicators of metapragmatic awareness

All of the markers identified above perform both pragmatic and metapragmatic functions. However, an investigation of the metapragmatic dimension of pronouns, shifters, and so on, forces one to consider the interpretive processes involved when using such linguistic elements. More specifically, it forces one to take those interpretive processes into account which are marked in discourse. Subjectivity may be marked with varying degrees of implicitness and explicitness in discourse. For instance, the meaning and function of the pronoun 'you' and the special qualifier 'this' in an utterance such as 'you simply can't do this', can only make sense if we are provided with some markers that indicate some of the relevant aspects of reality required for interpretation. These aspects may be marked indexically in preceding or following discourse (words, topics, 
intonation, ...), in non-verbal aspects of communication (e.g. gaze, pointing, ...), or any other aspect of communication that provides relevant indexical parameters.

Before discussing the heuristic and the analysis below, we should mention some of the social and evaluative functions of metapragmatic discourse. Hübler and Bublitz note that metapragmatic performances serve as a means of commenting on and interfering with ongoing discourse or text (Hübler and Bublitz 2007: 6). As such, these performances are fundamental to the articulation of social and textual critique. Moreover, there is a social function that needs to be mentioned. Hyland considers metadiscourse as the deployment of linguistic tokens in order to guide or direct a reader through a text so both the text and the writer's stance is understood. Metapragmatic markers perform various communicative functions defined in terms of communicative purposes for language users. Hyland emphasises that such "functional analyses recognize that a comprehensive and pragmatically grounded description of any text must involve attending to the use of language in relation to its surrounding co-text and the purpose of the writer in creating a text as a whole" (Hyland 2005: 18, 24).

Considering the multiplicity of reflexive and social functions of metapragmatic discourse, it is safe to assume that it performs a key function in the articulation of political subjectivities and discourses. This point will be amply illustrated in the analysis below. For now, we may conclude with some definitions: Metapragmatics may be described as "the systematic study of the metalevel, where indicators of reflexive awareness are to be found in the actual choice-making that constitutes language use, is the proper domain of what is usually called metapragmatics" (Verschueren 1999: 188). Secondly, metapragmatic awareness can be defined as a mental awareness of the way an aspect discourse is (or should be) used. Like any other reflexive process related to language use, metapragmatic awareness may or may not be marked explicitly in discourse. Lastly, metapragmatic markers are basically discursive (linguistic or nonlinguistic) items that mark mental awareness of the way an aspect of discourse is (or should be) used (Zienkowski 2011b: 432). As such, they are empirically observable indicators of large-scale interpretive logics giving rise to the discourse generated by individuals.

\section{An interpretive and functionalist heuristic for articulating metapragmatic markers with discourse topics in Mourning Bologna}

The concepts of logics and metapragmatic markers were initially formulated in very different types of (post-structuralist) discourse theory and (linguistic pragmatic) analysis. Nevertheless, it is worth articulating both frameworks with one another. Below, I will illustrate how metapragmatic markers allow for an identification of interpretive logics. As an exemplary case study, I have opted for an analysis of Dietrich Lemke's critical response to the implementation of the Bologna process in Germany as published in the $14^{\text {th }}$ issue of the journal E-flux. The article under discussion is titled Mourning Bologna. We already noticed the successful operation of a logic of equivalence with respect to the various German interpretations and implementations of the Bologna process. This logic has made it increasingly difficult to think outside of the hegemonic box provided by dominant and interchangeable discourses on higher education (Maeße 2010: 135-44). It is therefore worth looking into the way an individual wields discursive resources in such a way that he is enabled to articulate a critical stance towards dominant interpretations of the process. 
In order to distinguish between Lemke's metapragmatic comments with respect to the dominant interpretations of the Bologna process and my own analysis of Lemke's discourse, I will make use of the rearticulations markers $\langle$ and $\rangle$. These markers highlight those sections of the text where it is important to illustrate that the words used by the author are literally the same words as used in the text under investigation. These markers are basically metapragmatic contextualisation cues that highlight when and where the wordings of researcher and research subject overlap. They should be conceptualised as tools that allow the reader to differentiate between: (1) my own analyses made within the context of this document; and (2) the voice(s) articulated within the context of Lemke's text. Moreover, they mark those points where Lemke's voice is consciously rearticulated with my own. Below, I will illustrate how one may identify metapragmatic markers and discuss why it is important to link them with other units of discursive organisation such as discourse topics. I will also illustrate how metapragmatic markers can be brought to bear on large-scale interpretive logics deployed by Lemke in his articulation of a critical stance towards the Bologna process.

Metapragmatic markers are functional entities. Since any function is basically a relationship between aspects of reality, we need to ask ourselves how these markers are interpretively related to relevant aspects of Lemke's argumentation. Moreover, since metapragmatic markers indicate how a discursive (linguistic or non-linguistic) item is (or should be) used (by and according to a language user), this entails that we need to analyse the discursive item that is the object of the metapragmatic remark as well. For this reason, I coded Lemke's text in terms of discourse topics. In the analysis below, we will ask ourselves what function(s) a specific metapragmatic marker performs in relation to the discourse topic that is being discussed at that point. My interpretive and functionalist approach to discourse analysis involves an investigation of the functional relatedness of linguistic forms to one another, to the practice(s) of interaction, and to the metapragmatic positioning of the interlocutors and voices involved in the speech event under investigation. The practice under investigation is a critique of the Bologna process articulated by Dietrich Lemke throughout a range of topics articulated in his article Mourning Bologna. I will not restrict myself to an investigation of a specific linguistic form. Rather, I will investigate those forms which are used by Lemke in order to mark his metapragmatic awareness of the critical practice he is involved in.

Metapragmatic markers enable us to investigate the self-interpretations of subjects - a prerequisite for the identification of fantasmatic, social, and political logics. It is therefore useful to start the analysis with a qualitative identification of the various explicit markers of metapragmatic awareness articulated in Lemke's text. Throughout the analysis, I have identified various explicit metapragmatic descriptions such as: Speech act verbs (e.g. to announce, to call, to herald, to define, to underline, to justify, to trumpet, to ask, to denounce, to demand, ...); nominalisations of speech act verbs (e.g. 〈name $\rangle,\langle$ discussion $\rangle$, 〈justification $\rangle,\langle$ response $\rangle,\langle$ protest $\rangle, \ldots$...). Self-referential expressions where the author metapragmatically marks Lemke's awareness of linguistic

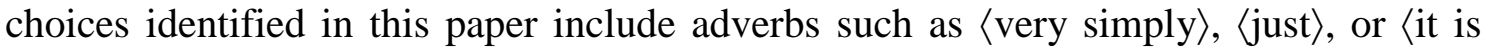
now clear $\rangle$. Interesting discourse markers indicating metapragmatic awareness comprise all instances where the author uses quotation marks in order to mention a particular

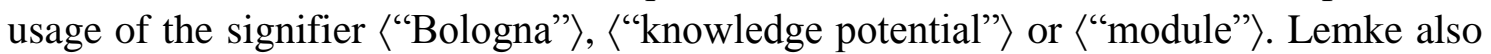
uses quotation marks as a means to mark direct reported speech and uses the various speech act verbs mentioned above in order to wield indirect reported speech. All of the metapragmatic markers above contribute to the explicit or implicit (re)articulation of the 
voices of a variety of social actors - including $\langle$ media $\rangle$, 〈politicians $\rangle$, 〈critical students $\rangle$, and $\langle$ more reflective souls $\rangle$ in the text. Modal verbs used in order to highlight his awareness of the way he and others use language include verbs such as to seem or to may. I also identified more elaborate metapragmatic comments such as /with sparse content and negligible effect〉, 〈which may in truth be called its destruction>, or 〈underlying the ultimate justification for the process, the text's next paragraph affirms and so on. There are many more examples of metapragmatic markers, but this list suffices for purposes of illustration.

The above examples illustrate that it is impossible to make sense of metapragmatic markers without relating them to relevant aspects of the context wherein they are uttered. An interpretive and functionalist analysis of these markers requires a focus on contextual aspects of the overall argumentation. In this particular case, I have opted to code the various discourse topics ${ }^{7}$ that structure Lemke's argumentation. Labelling extended stretches of discourse on a topical level allows for a rudimentary contextualisation of the metapragmatic markers under discussion. It is possible to distinguish between local topics (of sentences, utterances, and short discourse segments) and discourse topics (of more extended stretches of discourse). Discourse topics are expressible as noun phrases. They may consist of multiple levels of subtopics. Key lexical items in discourse can be indicative of a topic (see: Watson Todd 2005: 94). The excerpt below is coded under the discourse topic 'the loss of Bologna's good name'. The choice for this label is based on lexical aspects of Lemke's own formulation.

The venerable old Italian university town of Bologna seems in danger of losing its longestablished good name. The risk to the city's reputation, ironically enough, is due to developments in higher education, the very field in which its fame was established. In 1088, the first European university to be broadly independent of Church control was founded in Bologna, setting new standards in jurisprudential scholarship and, through its example, leading to the founding of other universities across the continent.

Excerpt 1 - excerpt from Dietrich Lemke's Mourning Bologna coded as 'the loss of Bologna's good name'

Discourse topics play a crucial role in the establishment of interpretive coherence. As a result of the coding process, we may give a chronological overview of the discourse topics discussed by Lemke. It is important to bear in mind that the labels enumerated below all rearticulate the original wordings as they have been articulated in the text by Lemke himself. In the remainder of this article, single quotation marks indicate a coded discourse topic.

Lemke starts his article by discussing 'the loss of Bologna's good name' and goes on to discuss the "contemporary usage of the label "Bologna". He then gives a brief narrative description of 'the development of the Bologna process' and of the 'justification and celebration of the Bologna process' by a variety of social actors. This allows him to highlight the 'failures, deficiencies and problems of the Bologna process'. According to Lemke 'educational institutions treating the symptoms of the Bologna process' do not manage to address the 〈basic problem〉 of the process - i.e. 〈the creation of graduates capable of critical thought and scholarly and scientific rigour $\rangle$. Neither do

${ }^{7}$ One may also choose to relate metapragmatic markers to other levels of discursive organisation such as identity labels, subject positions, voices, narratives, or conversational turns. The important thing is that one finds a way of relating these markers with key aspects of the context wherein they operate. 
the 'political responses to the Bologna illness' live up to Lemke's expectations and 'ideology critique'. At this point, the author starts to discuss 'patterns in the implementation process'. He discusses the issue of 'discussion and protest with respect to the Bologna process' and criticises the 'restructuring of faculties into modules'. Lemke takes a critical stance to what he calls 'the control oriented mentality underlying the Bologna process and the return to primitive pedagogy'. He offers 'the implementation of the Europe-Wide credit-point system as an example of primitive pedagogy'. Summarising his conclusions, Lemke deals with 'the failed restructuring of the German educational system' in the wake of Bologna, with 'the three-year bachelor as an officially certified dropping-out', and with 'the neoliberal Zeitgeist and the withdrawal of the state from higher education'. The last discourse topic is coded as 'predictions and the true meanings of the Bologna process'.

At this point, it becomes possible to systematically relate metapragmatic markers to the context of the discourse topics wherein they are uttered. From a pragmatic perspective, research questions should always be functional. For instance, if we take a look at the usage of quotation marks around lexical items such as 〈“Bologna"〉, 〈"module"〉, or 〈"knowledge potential"〉, one may deploy this heuristic to functionally relate these markers to the topics under discussion. This results in a research question such as: What metapragmatic function(s) do the quotation marks around ("Bologna") perform in relation to the discourse topic 'contemporary usage of the name "Bologna". In a similar way, the quotation marks around 〈module〉 and $\langle$ knowledge potential $\rangle$ may be functionally and interpretively related to the discourse topics of 'restructuring faculties into modules' and 'justifications and celebrations of the Bologna process' respectively. Such open-ended research questions may be answered in a variety of ways. However, the type of functionality we are interested in relates first and foremost to the way linguistic forms with a metapragmatic function allow Lemke to articulate a critical stance toward the Bologna process ${ }^{8}$.

\section{Research Results}

\subsection{Differentiating voices by means of metapragmatic markers}

In all of the cases mentioned above, Lemke's quotation marks function as hedges. Hedges are relevant to subjectivity in a variety of ways. They make messages indeterminate and convey inexactitude in order to mitigate or reduce the strength of the assertions that speakers or writers make. They highlight the fuzziness, vagueness, emptiness, or polysemy of a notion. A hedge may affect the truth-conditions of a proposition (e.g. 'sort of'; 'about'; 'roughly'). It may also introduce fuzziness in the relationship of the speaker's commitment to the propositional content of what is conveyed. A hedge may thus function as an approximator or as a shielding device protecting the speaker from potentially risky claims or other speech acts that might violate conversational maxims. (see Hyland 2000: 179; McLaren-Hankin 2008: 639; Verschueren 1999: 193; 2011: 179). All of this applies to Lemke's usage of quotation

\footnotetext{
${ }^{8}$ From a pragmatic perspective, the notion of function can be conceptualised as a flexible and temporal relationship between semiotic elements that establish a context by means of indexical processes of meaning generation.
} 
marks around notions such as $\langle$ Bologna $\rangle$, 〈module $\rangle$ or $\langle$ knowledge potential $\rangle$. Through his usage of hedges around these notions, Lemke opens up the semiotic space in which he can articulate his own alternative interpretation of these concepts.

The category of hedges also includes metapragmatic comments such as /what is known as $\rangle$. A first usage of the notion of 〈Bologna〉 occurs within the context of the discourse topic 'the loss of Bologna's good name'. Lemke uses the modal verb to seem as a hedge when he states that: 〈The venerable old Italian university town of Bologna seems in danger of losing its long-established good name $\rangle$. According to Lemke, the $\langle$ city's reputation $\rangle$ is grounded in its revolutionary independence with respect to $\langle$ Church control $\rangle$ and by its role in $\langle$ setting new standards in jurisprudential scholarship $\rangle,\langle$ leading to the founding of other universities across the continent $\rangle$. Bologna's good name is not yet completely lost, even though it $\langle$ seems $\rangle$ to be the case.

\begin{tabular}{|c|c|c|}
\hline $\begin{array}{l}\text { Metapragmatic } \\
\text { category }\end{array}$ & Examples of linguistic form(s) & Metapragmatic function(s) \\
\hline \multirow[t]{2}{*}{ Hedges } & 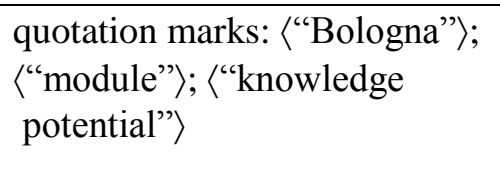 & \multirow{2}{*}{$\begin{array}{l}\text { - to convey inexactitude; to mitigate the } \\
\text { strength of assertions } \\
\text { - to affect the truth conditions of a } \\
\text { proposition } \\
\text { - to open up semiotic space for alternative } \\
\text { interpretations and critique } \\
\text { - to index the position of a speaker vis à vis } \\
\text { - the discourse (s)he produces } \\
\text { - to provide reference points for large-scale } \\
\text { interpretive processes }\end{array}$} \\
\hline & $\begin{array}{l}\text { Modal verbs: }\langle\text { seems }\rangle \\
\langle\text { should }\rangle,\langle\text { can }\rangle\end{array}$ & \\
\hline \multirow[t]{3}{*}{ Boosters } & $\begin{array}{l}\text { Adverbial expressions: 〈in } \\
\text { truth }\rangle\end{array}$ & \multirow{3}{*}{$\begin{array}{l}\text { - to emphasise what one believes to be } \\
\text { correct } \\
\text { - to indicate awareness of the normativity } \\
\text { of what one says } \\
\text { - to indicate a preferred mode of discourse, } \\
\text { interpretation and /or subjectivity } \\
\text { - to provide reference points with respect to } \\
\text { other actors and voices }\end{array}$} \\
\hline & $\begin{array}{l}\text { Nominalisation of a speech act } \\
\text { verb combined with an adverb: } \\
\text { 〈obvious question }\rangle\end{array}$ & \\
\hline & $\begin{array}{l}\text { Metapragmatic comments: "it } \\
\text { is now clear"; "to expose the } \\
\text { true meanings" }\end{array}$ & \\
\hline
\end{tabular}

Table 2 - illustration of metapragmatic functions and linguistic forms categorised as hedges and boosters

Hedges are the opposite of boosters that emphasise what one believes to be correct and indicate metapragmatic awareness of the normativity of what one is saying (see Hyland 2000: 179; McLaren-Hankin 2008: 639; Verschueren 1999: 193; 2011: 179). Lemke's usage of the adverbial expression 〈in truth〉 within the context of the discourse topic 'ideology critique' provides us with an example of a booster. Within the context of this discourse topic, he claims that $\langle$ ideology critique $\rangle$ provides us with an answer to what he considers to be the $\langle$ basic problem $\rangle$ of the $\langle$ Bologna Illness $\rangle$. Whereas both $\langle$ higher education institutions $\rangle$ and $\langle$ politicians $\rangle\langle$ fail to address $\rangle\langle$ and even fail to mention the basic problem $\rangle$, 〈ideology critique $\rangle$ allows us to identify the $\langle$ truth $\rangle$ of the process. Lemke describes the basic problem as 〈Bologna's abandonment of what should be the 
central idea of higher education - the creation of graduates capable of critical thought and scholarly and scientific rigour . He then asks himself the 〈obvious question〉 (a booster + a nominalisation of a speech act verb) $\langle$ why $\rangle$ parties of all political colours cling doggedly to Bologna $\rangle$. The 〈answer $\rangle$ provided by 〈ideology critique $\rangle$ is that this is due to $\langle$ the influence of interest groups that benefit and want to continue to benefit, from the failed Bologna process $\rangle$. Elsewhere in the text, Lemke concludes that $\langle$ it is now clear〉 (booster) 〈that Bologna's large-scale restructuring of the German higher education system has failed to achieve a single one of the objectives it announced $>$. Another interesting booster occurs when he arrives at his final conclusions in the context of the discourse topic 'predictions and the true meanings of the Bologna process'. In his last sentence, Lemke writes that (it is up to critical academics, dissenting students, and the first signs of resistance within the trade union movement to expose the true meanings of Bologna .

Boosters and hedges index the position of a speaker with respect to the discourse he or she produces. As such, this type of metapragmatic markers allows us to distinguish between the logics a speaker considers to be operative in society or in the subjectivity of others on the one hand, and the logics operative in one's preferred mode of interpretation and subjectivity on the other. As such, markers of metapragmatic awareness may function as reference points for an analysis of large-scale interpretive processes and logics. There are obviously many more metapragmatic markers and functions in Lemke's text than the ones discussed in this research article. Even though it is important to devote due attention to all of them in the analytical stage of the research process, it is not necessary to report them all here. Within the context of this research article, it is more important to ask ourselves how we can relate metapragmatic markers to large-scale interpretive processes.

\subsection{Articulating metapragmatic markers with interpretive logics and subjectivity}

Once we have investigated how metapragmatic markers functionally relate to the discourse topics wherein they occur, we need to ask ourselves how we can link all of this with large-scale interpretive processes that structure the awareness of self, others, and society in the text. These processes will be described in terms of the social, political, and fantasmatic logics of critical explanation. Howarth and Glynos have provided us with an important heuristic guideline: Any identification of a logic should go at least partially through the self-understanding of the research subject(s) at hand. Metapragmatic markers allow us to do this. It is interesting to note that Lemke uses the pronoun $\langle\mathrm{I}\rangle$ only once in the text. Other self-reflexive pronouns such as me or my do not occur at all. Nevertheless, Lemke does manage to articulate a highly politicised subjectivity with respect to the Bologna process through his usage of metapragmatic markers.

If we are to identify Lemke's preferred mode of subjectivity and the associated logics that structure his interpretive process, we need to distinguish between (1) the societal processes, actors, actions, and interpretations he denounces but nevertheless (re)articulates in his text, and (2) the societal processes, actors, actions and interpretations that make up his preferred mode of subjectivity. The concept of a logic is a concept of interpretive rules that establish articulations between semiotic elements. At the same time it constitutes these elements. When Lemke describes the <neoliberal 
Zeitgeist $\rangle$, this does not mean that he subscribes to the associated neoliberal logic and neoliberal actors. Also, an analysis of the interpretive processes deployed and marked by Lemke in his text does not mean that one is forced to subscribe to Lemke's analysis.

When I identify a neoliberal logic in Mourning Bologna, this means that I explicate those interpretive rules deployed by Lemke that allow him to construct a more or less coherent and oppositional subjectivity with respect to the various relations, practices, and actors which constitute this 〈neoliberal Zeitgeist〉 or logic according to him. The distinction between the logics a subject prefers and the logics an individual considers to be operative in society is not made within contemporary Essex frameworks. Nevertheless, if we are to analyse subjectivity and self-interpretations adequately, it is important to take this distinction into account. An articulation of (meta)pragmatic frameworks with post-structuralist thought allows us to address this issue explicitly. The necessity of an integration of the principle of indexicality can be illustrated with reference to Lemke's deployment of metapragmatic markers in order to distinguish his own voice and discourse from the voices and discourses he opposes. It might be claimed that the deployment of a word such as $\langle$ neoliberal $\rangle$ or $\langle$ critical $\rangle$ already indexes certain values and positions within a specific context of utterance. However, when I identify a neoliberal logic, I will only do so because this wording overlaps with Lemke's own formulations. The naming of a logic goes hand in hand with the identification of patterns of word-usage in the discourse under analysis. As such, the identification of a critical logic or a neoliberal logic does not necessarily imply agreement or rejection of Lemke's analysis. It is not a statement of an objective state of affairs in the world ${ }^{9}$. Rather, it is a statement about the way Lemke articulates his (self-)interpretation and subjectivity in a text. Articulation markers $\langle$ and $\rangle$ allow us to keep these caveats in mind.

Throughout his text, Lemke systematically relates various practices, actors, and interpretations with one another into two broad chains of equivalence. On the one hand,

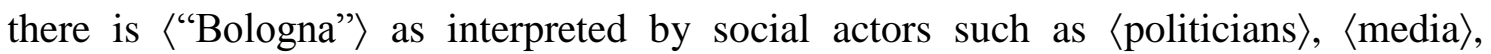
$\langle$ industry , and 〈conforming students $\rangle$. These actors are put in a relationship of equivalence to one another, since they are all involved in the justification $\rangle$ (speech act) of the 〈Bologna process〉 in terms of making (better use of the knowledge potential available $\rangle$ (metapragmatic description). It is important to note that this particular interpretation of the 〈process〉 is connected to what Lemke considers to be a 〈very narrow definition of higher education as equipping citizens to the labour market $\rangle$ (nominalisation of a speech act verb and a metapragmatic description). While $\langle$ media rhetoric and government sources have trumpeted (metaphorical speech act) the $\langle$ supposed success of the process $\rangle$, 〈more reflective souls may be struck by the $\langle$ narrow definition of education $\rangle$ deployed by their less reflective opponents in the Bologna debate.

On the other hand, Lemke's 〈more reflective souls〉 are put on a chain of equivalence with $\langle$ critical academics $\rangle$, 〈dissenting students $\rangle$, and those who are engaged

\footnotetext{
${ }^{9}$ It is perfectly possible to analyse the interpretive logics (social, political, fantasmatic) deployed by a multiplicity of individuals or groups. Logics are conceived of in terms of Wittgensteinian rules that do not exist independently from practice. The concept of logic may therefore designate the rules according to which discourse and subjectivities are produced in text, as well as processes in the social world one claims to speak about. From an Essex point of view, such a realist distinction does not make sense anyway.
} 
in the 〈first signs of resistance within the trade union movement $\rangle$ in order to 〈expose the true meanings of Bologna (metaphorical speech act and booster). These social actors are articulated with one another through the deployment of Lemke's preferred interpretation of 〈the central idea of higher education $\rangle$ as a practice directed at $\langle$ the creation of graduates capable of critical thought and scholarly and scientific rigour $\rangle$. It is also connected to an adherence to the old connotations of 〈Bologna in terms of independence of $\langle$ Church control $\rangle$ and high academic $\langle$ standards $\rangle$. It is now time to look into what 〈the true meanings of Bologna〉 are according to Lemke. Whereas the identification of the logic of equivalence as deployed by Lemke allows us to see how he polarises political space with respect to the Bologna process, this is a very formal logic. In order to see what (interpretations of) actors and social practices are put in opposition to one another, we need to identify the social logics of critical explanation.

Lemke identifies various societal and interpretive processes that account for the

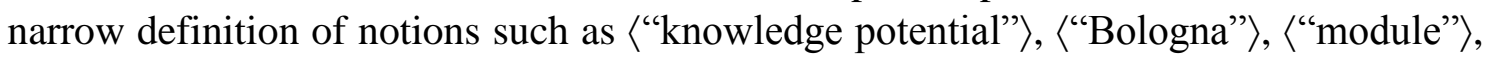
and 〈education〉. Sticking to Lemke's own word usage, we may distinguish between a neoliberal logic and a critical logic standing in direct opposition to one another. In his conclusion, Lemke writes that 〈the real〉 (booster) 〈reason behind the federal states' energetic implementation of the Bologna reforms〉 resides in 〈substantial reductions in state education costs $\rangle$. Moreover, he points out that this is $\langle$ in line with the prevailing neoliberal zeitgeist $\rangle$ wherein 〈the costs of higher education〉 are shifted from 〈the state $\rangle$ to the shoulders of $\langle$ students and outside interest groups - above all, onto industry and finance - whatever the cost to academic freedom and the integrity of research $\rangle$. This $\langle$ neoliberal zeitgeist $\rangle$ and the corresponding shift of responsibilities is posited as a given. Put differently, from Lemke's point of view, neoliberalism has a logic of its own that generates various practices associated with the $\langle$ Bologna process $\rangle$ : The restructuring of the $\langle$ faculty $\rangle\langle$ into new multifunctional (and polyvalent modules) $\rangle$; $\langle$ a control oriented mentality underlying the Bologna process that is exhibited in a basic distrust of students and an insistence on constant, and often unnecessary classroom attendance $\rangle$; 〈standardization〉 and the 〈breaking up of learning into bite-sized chunks, chunks then linked together in a system of incessant and immediate testing $\rangle$. Lemke deplores this, since he considers 〈the prevailing desire to control educational outputs〉 to lead 〈to the privileging of simplistic pedagogical aims $\rangle$. According to him, all of $\langle$ this can be seen clearly in the implementation of the ECTS, the new Europe-wide credit-point system $\rangle$. In addition to a neoliberal logic, we may identify other social logics that structure the German educational landscape as depicted by Lemke. For instance, it would be possible to identify a logic of standardisation, a logic of control, a logic of unification, and/or a logic of cost-effectiveness, since he explicitly mentions all of these processes in his text. Every single one of these processes implies the operation of an interpretive logic through which a variety of actors, practices, concepts, goals, and other relevant elements of the Bologna discourse are relate to one another in particular ways. It goes without saying that all of these logics overlap and should be thought of in terms of heuristic tools that allow us to deal with large-scale interpretive and societal processes.

It is possible to identify a social logic that stands in direct opposition to the dominant neoliberal logic or Zeitgeist that Lemke considers to be hegemonic in our day and age. This logic operates at a largely implicit level in his own argumentation. Nevertheless, at multiple points in the text, he deploys metapragmatic markers that allow for an empirical analysis of his own interpretive logic and subjectivity. Of course, 
the neoliberal logic identified above negatively defines his own preferred mode of subjectivity and education. Nevertheless, there is also a particularity that characterises the critical logic deployed by himself. The critical logic is deployed by what Lemke

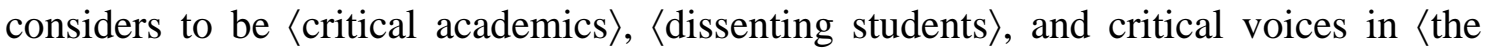
trade union movement $\rangle$. We also noted how Lemke wishes them $\langle$ to expose the true meanings of Bologna (a metapragmatic description of a metaphorical speech act verb). These 〈true meanings〉 are posited as objectively observable entities that can be described in terms of the neoliberal logics of standardisation, control, unification, and cost-effectiveness articulated above. Lemke wrote that $/$ more reflective souls may be struck by the very narrow definition of higher education as equipping citizens for the labour market〉 (metapragmatic description). Moreover, 〈they may even ask $\rangle$ (speech act verb) 〈who could or should profit form a more successful exploitation of this "knowledge potential" $\rangle$. Considering the fact that he subscribes to the answer provided by 〈ideology critique, it is safe to state that he considers himself to be one of these $\langle$ reflective souls〉 who are engaged in the speech act of asking /who could or should profit $\rangle$ from the $\langle$ Bologna process $\rangle$.

\begin{tabular}{|c|c|c|}
\hline & Neoliberal logic & Critical logic \\
\hline $\begin{array}{l}\text { Associated social actors / } \\
\text { voices / subject positions }\end{array}$ & $\begin{array}{l}\langle\text { politicians }\rangle ;\langle\text { media }\rangle ; \\
\langle\text { industry }\rangle ;\langle\text { conforming } \\
\text { students }\rangle\end{array}$ & $\begin{array}{l}\langle\text { more reflective souls }\rangle ; \\
\langle\text { dissenting students }\rangle \text {; parts } \\
\text { of the }\langle\text { trade union } \\
\text { movement }\rangle \text {; }\end{array}$ \\
\hline $\begin{array}{l}\text { Examples of metapragmatic } \\
\text { characterisations by } \\
\text { Dietrich Lemke }\end{array}$ & $\begin{array}{l}\text { involved in a process of } \\
\text { 〈justification }\rangle \text { in terms of } \\
\text { making }\langle\text { better use of the } \\
\text { knowledge potential } \\
\text { available }\rangle \text {; having a } \\
\langle\text { narrow definition of higher } \\
\text { education as equipping } \\
\text { citizens to the labour } \\
\text { market }\rangle\end{array}$ & $\begin{array}{l}\text { aiming }\langle\text { to expose the true } \\
\text { meanings of Bologna }\rangle \\
\langle\text { struck by }\rangle \text { the }\langle\text { narrow } \\
\text { definition of education }\rangle ; \\
\text { they }\langle\text { ask }\rangle\langle\text { who could } \\
\text { profit from a more } \\
\text { successful exploitation of } \\
\text { this "knowledge potential" }\rangle\end{array}$ \\
\hline $\begin{array}{l}\text { Examples of associated } \\
\text { practices }\end{array}$ & $\begin{array}{l}\text { shifting }\langle\text { the cost of higher } \\
\text { education }\rangle \text { from }\langle\text { the state }\rangle \\
\text { to }\langle\text { students and outside } \\
\text { interest groups }\rangle \text {; }\langle\text { breaking } \\
\text { up of learning into bite- } \\
\text { sized chucks }\rangle \\
\langle\text { standardization }\rangle\end{array}$ & $\begin{array}{l}\text { no specific practices } \\
\text { mentioned except for the } \\
\text { metapragmatic activities } \\
\text { characterised by Dietrich } \\
\text { Lemke. }\end{array}$ \\
\hline
\end{tabular}

Table 3 - Neoliberal and critical logics as articulated by Dietrich Lemke

Lastly, we need to deal with the fantasmatic logic as deployed by Lemke. Howarth and Glynos deploy the notion of fantasy to designate the processes whereby we can leave the radical contingency of discourse, social reality, and the political dimension of social practices in the background. The notion of fantasy is therefore a short-hand to designate those principles that allow us to act as if notions such as 〈criticism〉, 〈education〉, $\langle$ knowledge potential $\rangle$, and so on are not merely abstract notions but labels that refer un- 
problematically to aspects of our life-world. Once again, metapragmatic markers are useful tools to investigate the interpretive processes through which such fantasies are realised. On the one hand, Lemke politicises and highlights the fantasmatic nature of the various logics associated with neo-liberalism. This is frequently achieved by his usage of metapragmatic markers such as hedges, quotation marks, and various metapragmatic comments. We already noted how this strategy opens up semiotic space for Lemke's critical stance towards the Bologna process. On the other hand, there is a fantasmatic logic operative in his own interpretations as well. We may distinguish between a fantasmatic logic of contingency and a fantasmatic logic of necessity. The logic of contingency highlights the fact that alternative interpretations and meanings are possible. Put differently, it tends to highlight the political dimension of discourse. An awareness of this fact can be marked or indexed by modal verbs in cases such as 〈Bologna seems in danger of losing its long-established good name $\rangle$. Moreover, Lemke claims that $\langle$ the process, begun just over a decade ago, is intended to reduce the traditional diversity of European universities, standardizing and unifying them along "American" lines $\rangle$. He continues and claims that this 〈was done by unifying degrees, replacing them with the BA and the MA, and implementing the modularization of teaching, standardized testing, comparable outcomes, and other elements seemingly aimed at ensuring a unified field with greater mobility between countries and the greater parity before funding agencies $\rangle$. The modal operator $\langle$ seemingly $\rangle$ functions as a hedge and highlights the possibility of voices claiming that other aims were involved.

Alternative interpretations are frequently introduced by means of adverbs or boosters. These metapragmatic markers may thus help us to identify a logic of necessity that forces Lemke to interpret the Bologna process in this way and not in another. This is frequently established by means of claims to truth and / or to common sense. Moreover, a sense of contingency and necessity can be articulated by means of deontic modal verbs: 〈more reflective souls〉 〈may even ask who could or should profit from a more successful exploitation of this knowledge potential $\rangle$. The logic of necessity may be observed in appeals to common sense such as: 〈very simply (self-referential sentence adverb) 〈the politicians were just playing for time $\rangle$. Moreover, Lemke claims that in the light of a failing Bologna process, 〈Horst Köhler himself felt obliged to $\rangle$ (deontic modal verb) 〈denounce〉 (speech act) 〈the disgraceful failures and deficiencies in German higher education and to demand $\rangle$ (speech act) 〈improvements and new ideas for the future, rather than a continued sweeping-under-the-carpet $\rangle$ (metaphorical metapragmatic description). Other examples can be found in metapragmatic descriptions such as $\langle$ this meant that $\rangle$. Self-referential expressions functioning as boosters may perform similar functions as in 〈it is now clear that〉 (self-referential expression / booster) Bologna's large-scale restructuring of the German higher education system has failed to achieve a single one of the objectives it announced $>$ (speech act). The logic of necessity identified above is interpretive. The claim that Lemke is forced to interpret the Bologna process one way and not another should not be read as a bleak type of determinism. It merely means that if he metapragmatically positions himself towards the various processes or logics articulated in his Mourning Bologna, he is ethically compelled to take one stance instead of another. 


\section{Conclusion}

The analysis above demonstrates how the concept of metapragmatic markers may help us to identify the interpretive processes or logics that are constitutive of subjectivities and discourses. Nevertheless, at the beginning of this paper, I insisted that the articulation of both concepts should be embedded within a larger problematic of what an integrated linguistic pragmatic and post-structuralist perspective might look like. The principle of articulation entails that the meaning(s) of the articulated elements alter(s) throughout the articulatory practice itself. With respect to our current discussion, this can be exemplified by the fact that it is not possible to integrate the notion of (meta)pragmatic markers into the Essex approach to discourse without reconsidering the purely differential theory of meaning it inherited from Saussure. More specifically, the notion of indexicality or deixis has to be accounted for. On the other hand, the perspective of linguistic pragmatics might benefit from an integration of key poststructuralist insights with respect to large-scale discursive processes and the political implications of discourse and subjectivity. At any rate, the principle of articulation entails that neither perspective remains unaltered.

With respect to the empirical aspects of this analysis, we may conclude that Lemke succeeds in (re)articulating the discursive elements that make up the Bologna process in such a way that he is able to construct a critical stance towards dominant interpretations of the process - critical in the sense of the 〈ideology critique〉 proposed by Lemke himself. Metapragmatic markers are of key importance to understanding how Lemke is able to construct the interpretive logics and entities he opposes in contrast to those he prefers. The various logics that structure his argumentation and political subjectivity with respect to the Bologna process may be summarised schematically. The logic of equivalence allows us to distinguish between two sets of social and fantasmatic logics:

\begin{tabular}{|c|c|}
\hline Neoliberal logic & Critical logic \\
\hline $\begin{array}{l}\text { Social actors responsible for the } \\
\text { deployment of this logic: }\langle\text { politicians }\rangle, \\
\langle\text { media }\rangle \text {, }\langle\text { industry }\rangle \text {, conforming }\langle\text { students }\rangle\end{array}$ & \multirow{5}{*}{$\begin{array}{l}\text { Social actors responsible for the } \\
\text { deployment of this logic: }\langle\text { more reflective } \\
\text { souls }\rangle \text {, critical voices in the }\langle\text { unions }\rangle \text {, } \\
\langle\text { critical students }\rangle\end{array}$} \\
\hline Logic of control & \\
\hline Logic of unification & \\
\hline Logic of standardisation & \\
\hline Logic of cost-effectiveness & \\
\hline Logic of necessity & Logic of contingency \\
\hline
\end{tabular}

Table 4 - overview of logics identified in Dietrich Lemke's Mourning Bologna

Metapragmatic markers allow Lemke to challenge the meaning(s) of various elements related to the Bologna process and to propose his own preferred interpretation of notions such as 〈education〉. They provide a set of tools that may be deployed as a counter-measure to the post-structuralist methodological deficit. Moreover, they allow for an empirical analysis of metapragmatic awareness and self-interpretations of subjects. Even though metapragmatic markers are not the only linguistic elements indicative of subjectivity, they are certainly useful tools.

Moreover, the concept of a logic allows us to link the various locally produced markers of metapragmatic awareness to one another. It allows us to see how we 
systematically articulate our own subjectivity with respect to and through a whole series of articulated subject positions, attitudes, concepts, utterances, narratives, and stances. It allows us to identify the specific ways in which one embarks on a futile but productive quest for establishing coherence and fixation of meaning in discourse and subjectivity. These positionings are not merely differential, but also function through the principle of indexicality by means of empirically observable indexical markers and expressions. One of their functions being metapragmatic.

With respect to the larger problematic of articulating post-structuralist to linguistic pragmatic thought, the empirical results demonstrate that an integrated perspective still adheres to the principles characterising both perspectives: The relative fixation of discursive forms and functions; the impossibility of being either fully explicit or fully implicit in discourse; and the idea that context is generated throughout discourse itself are still operative. However, whereas the Essex approach muses upon these principles and their implications with respect to the nature of politics, hegemony, discourse, and subjectivity, the linguistic pragmatic approach to discourse allows us to empirically investigate how these principles operate in empirically observable language use. Thus, it is safe to assume that the notion of metapragmatics is just one among many concepts that may be deployed in order to overcome the post-structuralist methodological deficit.

There are many issues left to be explored. In addition to the question of exactly what other linguistic pragmatic notions may be articulated with post-structuralist theories of discourse, we may ask ourselves to what extent the approach set out in this paper can be deployed in a comparative manner. In this paper, I demonstrated how we may analyse the interpretive logics of one individual. It goes without saying that an analysis of the Bologna debate as such requires comparing the various logics deployed by a multiplicity of social actors. Even though I am convinced that such an approach is feasible (Zienkowski 2011b) ${ }^{10}$, it definitely requires a significant effort to tackle large amounts of data in the manner proposed above. Also, we may ask ourselves in what ways it is possible to link up with quantitative approaches in discourse analysis. These are just a few of many questions left to be explored.

\section{References}

Angermüller, Johannes (2007) Was fordert die Hegemonietheorie? Zu den Möglichkeiten und Grenzen ihrer methodischen Umsetzung. In Martin Nonhoff (ed.), Diskurs - radikale Democratie - Hegemonie. Bielefeld: Transcript Verlag, pp. 170-84.

Angermüller, Johannes (2008) From discourse theory to discourse analysis. Doing Discourse Analysis Workshop (Denmark), 6. Manuscript.

Angermüller, Johannes (2011) From the many voices to the subject positions in anti-globalization discourse: Enunciative pragmatics and the polyphonic organization of subjectivity. Journal of Pragmatics 43: 2992-3000.

${ }^{10}$ I have analysed 45 in-depth interviews with intellectuals and activists involved in Flemish minority politics in a manner that closely resembles the method proposed in this paper. 
Barros, Sebastian, and Gustavo Castagnola (2000) The political frontiers of the social: Argentine politics after Peronist populism (1955-1973). In David Howarth, Aletta Norval, and Yannis Stavrakakis (eds.), Discourse theory and political analysis: Identities, hegemonies and social change. London/New York: Manchester University Press, pp. 24-37.

Bauman, Richard, and Charles Briggs (1990) Poetics and performance as critical perspectives on language and social life. Annual review of anthropology 19: 59-88.

Blommaert, Jan (2005) Discourse. Cambridge: Cambridge University Press.

Bowman, Glenn (1994) 'A country of words': Conceiving the Palestinian nation from the position of exile. In Ernesto Laclau (ed.), The making of political identities. London: Verso, pp. 138-70.

Bublitz, Wolfram, and Axel Hubler (eds.) (2007) Metapragmatics in use. Amsterdam: John Benjamins Publishing Company.

Butler, Judith (2000) Dynamic conclusions. In Judith Butler, Ernesto Laclau, and Slavoj Žižek (eds.), Contingency, hegemony, universality. London: Verso, pp. 263-80.

Butler, Judith, and Ernesto Laclau (2004) Appendix I: The uses of equality. In Simon Critchley, and Oliver Marchart (eds.), Laclau: A critical reader. London/New York: Routledge, pp. 329-44.

Butler, Judith, Ernesto Laclau, and Slavoj Žižek (eds.) (2000) Contingency, hegemony, universality: Contemporary dialogues on the left. London: Verso.

Caffi, C. (1998) Metapragmatics. In Jacob L. Mey (ed.), Concise encyclopedia of pragmatics. Amsterdam: Elsevier, pp. 581-86.

Chandler, Daniel (2002) Semiotics: The basics. London: Routledge.

Daryl Slack, Jennifer (1996) The theory and method of articulation in cultural studies. Stuart Hall: Critical dialogues in cultural studies. London/New York: Routledge, pp. 112-30.

Fairclough, Norman, and Lilie Chouliaraki (1999) Discourse in late modernity. Edinburgh: Edinburgh University Press.

Flyvbjerg, Bent (2001) Making social science matter: Why social inquiry fails and how it can succeed again. (2008 edition). Cambridge: Cambridge University Press.

Glynos, Jason, and Yannis Stavrakakis (2004) Encounters of the real kind: Sussing out the limits of Laclau's embrace of Lacan. In Simon Critchley, and Oliver Marchart (eds.), Laclau: A critical reader. London/New York: Routledge, pp. 201-16.

Glynos, Jason, and Davod Howarth (2007) Logics of critical explanation in social and political theory. London: Routledge.

Griggs, Steven, and David Howarth (2000) New environmental movements and direct action protest: The campaign against Manchester Airport's second runway. In David Howarth, Aletta Norval, and Yannis Stavrakakis (eds.), Discourse theory and political analysis: Identities, hegemonies, and social change. Manchester/New York: Manchester University Press, pp. 52-69.

Grossberg, Lawrence (1986a) History, politics and postmodernism. In David Morley, and Kuan-Hsing Chen (eds.), Stuart Hall: critical dialogues in cultural studies. London /New York: Routledge, pp. 15173.

Grossberg, Lawrence (1986b) On postmodernism and articulation: An interview with Stuart Hall. In David Morley, and Kuan-Hsing Chen (eds.), Stuart Hall: Critical dialogues in cultural studies. London/New York: Routledge, pp. 131-50. 
Gumperz, John J. (1982) Discourse strategies. Cambridge: Cambridge University Press, pp. 225.

Howarth, David (2000) Discourse. Buckingham: Open University Press.

Howarth, David (2005) Applying discourse theory: The method of articulation. In David Howarth, and Jacob Torfing (eds.), Discourse theory in European politics: Identity, policy and governance. New York: Palgrave/Macmillan, pp. 316-49.

Howarth, David, and Jacob Torfing (eds.) (2005) Discourse theory in European politics: Identity, policy and governance. New York: Palgrave/Macmillan, pp. 364.

Howarth, David, Aletta Norval, and Yannis Stavrakakis (eds.) (2000) Discourse theory and political analysis: Identities, hegemonies and social change. Manchester: Manchester University Press.

Huang, Yan (2007) Pragmatics. Oxford: Oxford University Press.

Hübler, Axel, and Wolfram Bublitz (2007) Introducing metapragmatics in use. In Wolfram Bublitz, and Axel Hübler (eds.), Metapragmatics in use. Amsterdam: John Benjamins Publishing Company, pp. 1-26.

Hyland, Ken (2000) Hedges, boosters and lexical invisibility: Noticing modifiers in academic texts. Language awareness 9.4: 179-97.

Hyland, Ken (2005) Metadiscourse: Exploring interaction in writing. London/New York: Continuum.

Jaworski, Adam, Nikolas Coupland, and Dariusz Galasinski (2004a) Metalanguage: Why now? In Adam Jaworski, Nikolas Coupland, and Dariusz Galasinski (eds.), Metalanguage: Social and ideological perspectives. Berlin/New York: Mouton de Gruyter, pp. 3-10.

Jaworski, Adam, Nikolas Coupland, and Dariusz Galasinzki (eds.) (2004b) Metalanguage: Social and ideological perspectives. Berlin/New York: Mouton de Gruyter.

Johansson, Marjut, and Eija Suomela-Salmi (2011) Énonciation. In Jan Zienkowski, Jef Verschueren, and Jan-Ola Östman (eds.), Discursive pragmatics. Amsterdam: John Benjamins Publishing Company, pp. $71-101$.

Laclau, Ernesto (1989) Preface. In Slavoj Žižek (ed.), The sublime object of ideology. London/New York: Verso, ix-Xv.

Laclau, Ernesto (1994a) Why do empty signifiers matter to politics?. In Ernesto Laclau (ed.), Emancipation(s). London: Verso, pp. 36-46.

Laclau, Ernesto (ed.) (1994b) The making of political identities. London: Verso, pp. 296.

Laclau, Ernesto (2000a) Constructing universality. In Judith Butler, Ernesto Laclau, and Slavoj Žižek (eds.), Contingency, hegemony, universality: Contemporary dialogues on the left. London: Verso, pp. 281-307.

Laclau, Ernesto (2000b) Identity and hegemony: The role of universality in the constitution of political logics. In Judith Butler, Ernesto Laclau, and Slavoj Žižek (eds.), Contingency, hegemony, universality: Contemporary dialogues on the left. London: Verso, pp. 44-89.

Laclau, Ernesto, and Chantal Mouffe (1985) Hegemony and socialist strategy: Towards a radical democratic politics. London: Verso, pp.198.

Levinson, Stephen C. (1983) Pragmatics. Cambridge: Cambridge University Press. 
Maeße, Jens (2010) Die vielen Stimmen des Bologna-Prozesses: zur diskursiven Logik eines bildungspolitischen Programms. Bielefeld: Transcript Verlag.

McLaren-Hankin, Yvonne (2008) We expect to report on significant progress in our product pipeline in the coming year: Hedging forward-looking statements in corporate press releases. Discourse studies 10.5: 635-54.

Noh, Eun-Ju (2000) Metarepresentation: A relevance-theory approach. Amsterdam: John Benjamins Publishing Company.

Robinson, Douglas (2006) Introducing performative pragmatics. London/New York: Routledge.

Roulet, E. (1996) Polyphony. Handbook of pragmatics online.

<http://www.benjamins.nl/online/hop>, accessed 22/06/2009.

Saleel, Renata (1994) The crisis of identity and the struggle for new hegemony in the former Yugoslavia. In Ernesto Laclau (ed.), The making of political identities. London: Verso, pp. 205-32.

Stavrakakis, Yannis (1999) Lacan and the political. London: Routledge.

Torfing, Jacob (1999) New theories of discourse: Laclau, Mouffe and Žižek. Oxford: Blackwell.

Torfing, Jacob (2005) Discourse theory: Achievements, arguments, and challenges. In David Howarth, and Jacob Torfing (eds.), Discourse theory in European politics: Identity, policy and governance. New York: Palgrave/Macmillan, pp. 1-32.

Van Hecke, Tine (2002) Emile Benveniste. Handbook of pragmatics online.

<http://www.benjamins.nl/online/hop/>, accessed 15/06/2010.

Verschueren, Jef (1999) Understanding pragmatics. (2003 edn.). London: Arnold.

Verschueren, Jef (2000) Notes on the role of metapragmatic awareness in language use. Pragmatics 10.4: 439-56.

Verschueren, Jef (2004) Notes on the role of metapragmatic awareness in language use. In Adam Jaworski, Nikolas Coupland, and Dariusz Galasinski (eds.), Metalanguage: Social and ideological perspectives. Berlin/New York: Mouton de Gruyter, pp. 53-74.

Verschueren, Jef (2009) Introduction: The pragmatic perspective. In Jef Verschueren, and Jan-Ola Östman (eds.), Key notions for pragmatics. Amsterdam: John Benjamins Publishing Company, pp. 1-27.

Verschueren, Jef (2011) Ideology in language use: Pragmatic guidelines for empirical research. Cambridge: Cambridge University Press.

Watson Todd, Richard (2005) A fuzzy approach to discourse topics. Semiotica 155.1: 93-123.

Wetherell, Maragaret (1998) Positioning and interpretative repertoires: Conversation analysis and poststructuralism in dialogue. Discourse and Society 9.3: 387-412.

Zienkowski, Jan (2011a) Discursive pragmatics: A platform for the pragmatic study of discourse. In Jan Zienkowski, Jef Verschueren, and Jan-Ola Östman (eds.), Discursive pragmatics. Amsterdam: John Benjamins Publishing Company, pp. 1-13.

Zienkowski, Jan (2011b) Analysing political engagement: An interpretive and functionalist discourse analysis of evolving political subjectivities among public activists and intellectuals with a Moroccan background in Flanders. Ph.D. dissertation. University of Antwerp. 


\section{Jan Zienkowski}

Zienkowski, Jan, Jef Verschueren, and Jan-Ola Östman (eds.) (2011) Discursive pragmatics. Amsterdam: John Benjamins Publishing Company, pp. 1-13.

Žižek, Slavoj (1995) The sublime object of ideology. London: Verso.

Žižek, Slavoj (2000) Class struggle or postmodernism? Yes, please!. In Judith Butler, Ernesto Laclau, and Slavoj Žižek (eds.), Contingency, hegemony, universality: Contemporary dialogues on the left. London: Verso, pp. 90-135.

JAN ZIENKOWSKI currently teaches a course called 'anthropological study of intercultural contact' at the Catholic University of Louvain (KULeuven). He is also employed by the Journalism Department of the Erasmushogeschool Brussel (EhB), and active as an associate researcher at the Department of Linguistics of the University of Antwerp (UA). For the past few years he has been working on a Ph.D., titled "Analysing political engagement'. This study offers an interpretive and functional analysis of discourse produced by public activists and intellectuals with a Moroccan background in Flanders. His areas of interest include linguistics, sociology, political philosophy, ethnographic anthropology, and communication studies. Empirically, he tends to focus on large-scale socio-polotical debates and on large-scale interpretive processes marked in discourses articulated by individuals. Related areas of interest include identity, subjectivity, ideology, hegemony, public interaction, minority politics, critique, linguistic pragmatics, pragmatism, and post-structuralist thought.

Address: University of Antwerp, Department of Linguistics, Rodestraat 14 - S.R. 216, 2000 Antwerp, Belgium. Tel.: +32-(0)494-716661; e-mail: jan.zienkowski@ua.ac.be 